\title{
Baghuk Mountain (Central Iran): high-resolution stratigraphy of a continuous Central Tethyan Permian-Triassic boundary section
}

\author{
Dieter Korn $^{1}$, Lucyna Leda ${ }^{1}$, Franziska Heuer ${ }^{1}$, Hemen Moradi Salimi ${ }^{1,2}$, Elham Farshid ${ }^{3}$, Amir Akbari $^{4}$, \\ Martin Schobben $^{5}$, Abbas Ghaderi ${ }^{6}$, Ulrich Struck ${ }^{1}$, Jana Gliwa ${ }^{1}$, David Ware ${ }^{1,7}$, and Vachik Hairapetian ${ }^{4}$ \\ ${ }^{1}$ Museum für Naturkunde Berlin, Leibniz Institute for Evolution and Biodiversity Science, \\ Invalidenstraße 43, 10115 Berlin, Germany \\ ${ }^{2}$ Geology Department, Faculty of Science, University of Isfahan, Isfahan, Iran \\ ${ }^{3}$ Department of Geology, North Tehran Branch, Islamic Azad University, Tehran, Iran \\ ${ }^{4}$ Department of Geology, Isfahan (Khorasgan) Branch, Islamic Azad University, Isfahan, Iran \\ ${ }^{5}$ Marine Palynology and Paleoceanography, Utrecht University, Princetonlaan, Utrecht, the Netherlands \\ ${ }^{6}$ Department of Geology, Faculty of Science, Ferdowsi University of Mashhad, P.O. Box 9177948974, Mashhad, Iran \\ ${ }^{7}$ Museum für Naturkunde, Otto-von-Guericke-Straße 68-73, 39104 Magdeburg, Germany
}

Correspondence: Dieter Korn (dieter.korn@mfn.berlin)

Received: 19 April 2021 - Revised: 18 May 2021 - Accepted: 27 May 2021 - Published: 23 June 2021

\begin{abstract}
Permian-Triassic boundary sections at Baghuk Mountain (Central Iran) are investigated with respect to their lithological succession, biostratigraphy (particularly conodonts, nautiloids and ammonoids) as well as chemostratigraphy (carbon isotopes). The rock successions consist of the Late Permian Hambast Formation, the youngest Permian Baghuk Member (new name for the "Boundary Clay") and the Early Triassic Claraia beds. Correlation of the data allows the establishment of a high-resolution stratigraphy based on conodonts with seven Changhsingian zones. Abundant ammonoids enable the separation of ammonoid assemblages with the successive Wuchiapingian genera Prototoceras, Pseudotoceras and Vedioceras, as well as the Changhsingian genera Shevyrevites, Paratirolites, Alibashites, Abichites and Arasella. Griesbachian and Dienerian ammonoids are usually poorly preserved. Nautiloids occur predominantly in the Wuchiapingian part of the section with two successive assemblages dominated by the Liroceratidae and Tainoceratidae, respectively. Numerous Early Triassic strata contain microbialites of various outer morphology and microstructure. The carbon isotope curve $\left(\delta^{13} \mathrm{C}_{\text {carb }}\right)$ shows a continuous late Changhsingian negative excursion continuing across the Baghuk Member with the lightest values at the base of the Triassic.
\end{abstract}

\section{Introduction}

The search for gapless sections spanning the PermianTriassic boundary has developed into an important geoscience project in recent years. The massive diversity decrease during the largest mass extinction in the history of the Earth (e.g. Erwin, 1993, 1994; Erwin et al., 2002; Alroy et al., 2008) has so far been intensively investigated in only a few regions, because fossil-rich sections are rare or difficult to access even on a global scale. For the palaeoequatorial marine realm, two regions are particularly important for the study of the biotic crisis at the turn of the Palaeozoic and Mesozoic; these are southern China with sections in different facies zones ranging from shallow to deep water (e.g. Jin et al., 2000; Yin et al., 2001; Song et al., 2013) and the area of Armenia, Azerbaijan as well as NW Iran with sections of sedimentary rocks of the deeper shelf (e.g. Ruzhencev, 1965; Teichert et al., 1973; Leda et al., 2014; Sahakyan et al., 2017; Friesenbichler et al. 2018; Gliwa et al., 2020; Leda, 2020).

The discovery of fossil-rich sedimentary successions ranging from the Permian into the Triassic at Baghuk Mountain in Central Iran (Fig. 1) opened up the possibility to study further sections regarding their lithological, geochemical and biological evolution before, during and after the extinction event. Baghuk Mountain is located only about $100 \mathrm{~km}$ away from the sections of the Hambast Mountains 
near Abadeh. Both regions show very similar lithological successions. However, both the number and the preservation of macrofossils at Baghuk Mountain are better than in the Hambast Mountains. The new, so far largely undescribed sections have a high potential for an important contribution to the decoding of the most severe mass extinction in Earth history.

In the following, we present an overview on various aspects (lithology, fossil content, stratigraphy, stable isotopes) of the Baghuk Mountain section. This study contributes to the understanding of the timing of the end-Permian biotic crisis as well as the ecological and sedimentological disturbances. Particular attention is paid to the lithostratigraphic and biostratigraphic succession as well as geochemical data. Detailed studies of various fossil groups (e.g. ammonoids, nautiloids) and microbial structures will be performed separately.

\section{Historical background}

Permian-Triassic (P-Tr) boundary sections in Central Iran (region of Esfahan and Abadeh) have only been known for a little over 50 years, but they have become very important for the study of the most severe extinction in the Phanerozoic. Sections in the Hambast Range $60 \mathrm{~km}$ south-east of Abadeh were discovered by Taraz in 1967 and the first studies focused on the lithological succession and the ammonoid content of these sections (Taraz, 1969, 1971, 1973, 1974; Bando, 1979, 1981; Taraz et al., 1981). These investigations formed a solid basis for further investigations with a stronger focus on sedimentological and geochemical issues.

A number of parallel sections in the Hambast Mountains and the later discovered section $14.5 \mathrm{~km}$ NNE of Shahreza have more recently been intensively investigated, e.g. for their conodont stratigraphy, facies, sedimentology and geochemistry using stable isotopes (Baud et al., 1997, 2021; Besse et al., 1998; Gallet et al., 2000; Partoazar, 2002; Yazdi and Shirani, 2002; Kozur, 2004, 2005, 2007; Horacek et al., 2007, 2021; Richoz et al., 2010; Heydari et al., 2013). Korte et al. (2004a) published a rather detailed $\delta^{13} \mathrm{C}_{\text {carb }}$ curve for the Hambast section. Liu et al. (2013) analysed the carbon and strontium isotope chemistry for this section. Chen et al. (2020) demonstrated, by using secondary ion mass spectrometry (SIMS) techniques for the analysis of oxygen isotopes in conodont apatite, a sudden warming of about $10^{\circ} \mathrm{C}$ immediately at the extinction horizon.

The conodont stratigraphy of sections in the Hambast Range was outlined by Kozur (2005, 2007), Richoz et al. (2010) as well as Shen and Mei (2010). In these articles it was shown that the latest Permian and earliest Triassic successions are very similar to the classical sections near Dzhulfa and Julfa in the Transcaucasian region. In the Hambast Range, for instance, the rock interval containing the Clarkina bachmanni to $C$. hauschkei zones (i.e., the time equivalent of the Paratirolites Limestone of Julfa) has a thickness of $3.65 \mathrm{~m}$. The overlying "Boundary Clay" (i.e. Baghuk Member) is about $0.7 \mathrm{~m}$ thick and is overlain by a "stromatolite-bearing limestone", named "colonial limestone" by Taraz et al. (1981) and "Calcite Fans" by Heydari and Hassanzadeh (2003) and Heydari et al. (2008); they are overlain by basal Triassic platy limestone beds. It was shown that these sections in Central Iran feature continuous rock successions; any evidence for a sedimentation gap is lacking.

Descriptions and interpretations of microbial structures in the Hambast sections were already published by Taraz et al. (1981). They reported massive and stratified algal biolithite ("colonial limestones") in the lowest portion of the Early Triassic limestone and designated them as thrombolite and planar stromatolite. Baghbani (1993) introduced the term "thrombolite zone" for the "stromatolite-thrombolite" unit of Taraz et al. (1981). Baud et al. (1972) and Stampfli et al. (1976) reported similar, laminated microbialites in the lowermost part of the Elikah Formation in the basal Triassic in the Elburz Range of northern Iran. Later, Heydari et al. $(2000,2001,2003,2013)$ described and discussed various types of microbial deposits from the Hambast and Shahreza sections in detail.

The first description of a Baghuk Mountain section was provided by Ghaedi et al. (2009), who used the name Benarizeh for the area. They recorded three biozones, from bottom to top Pseudogastrioceras beds, Paratirolites beds and Claraia beds and correlated them with the succession known from Julfa, Shahreza and Abadeh. Ghaedi et al. (2009) figured some cephalopod and bivalve specimens as well as fish remains; a microbialite was regarded as "algal remains" by these authors. Later, the general rock succession and carbonate microfacies of Baghuk Mountain sections was briefly outlined by Leda et al. (2014) and Leda (2020). Hampe et al. (2013) reported on Late Permian fish assemblages from Baghuk Mountain. Dudás et al. (2017) analysed samples from Baghuk Mountain (for which they also used the name Benarizeh) for a revision of the ${ }^{87} \mathrm{Sr} /{ }^{86} \mathrm{Sr}$ seawater curve across the Permian-Triassic boundary.

\section{Geographical and geological setting}

During the latest Permian to Early Triassic, the studied sites had a position in the Sanandaj-Sirjan Zone (Stöcklin, 1968; Nabavi, 1976; Stampfli and Borel, 2002, 2004; Torsvik and Cocks, 2004). This northwest-trending terrane is one of several structural units in Iran, distinguished in terms of stratigraphy, metamorphism and magmatism (Stöcklin, 1968; Ghorbani, 2013; Hassanzadeh and Wernicke, 2016). The Baghuk Mountain region was situated on the SSW part of the northern Neotethyan shelf (Fig. 2). According to Ruban et al. (2007), NW Iran, Central Iran, and the Sanandaj-Sirjan terrane are separate tectonic units that were apparently adjacent to each other. The Shahreza-Abadeh re- 

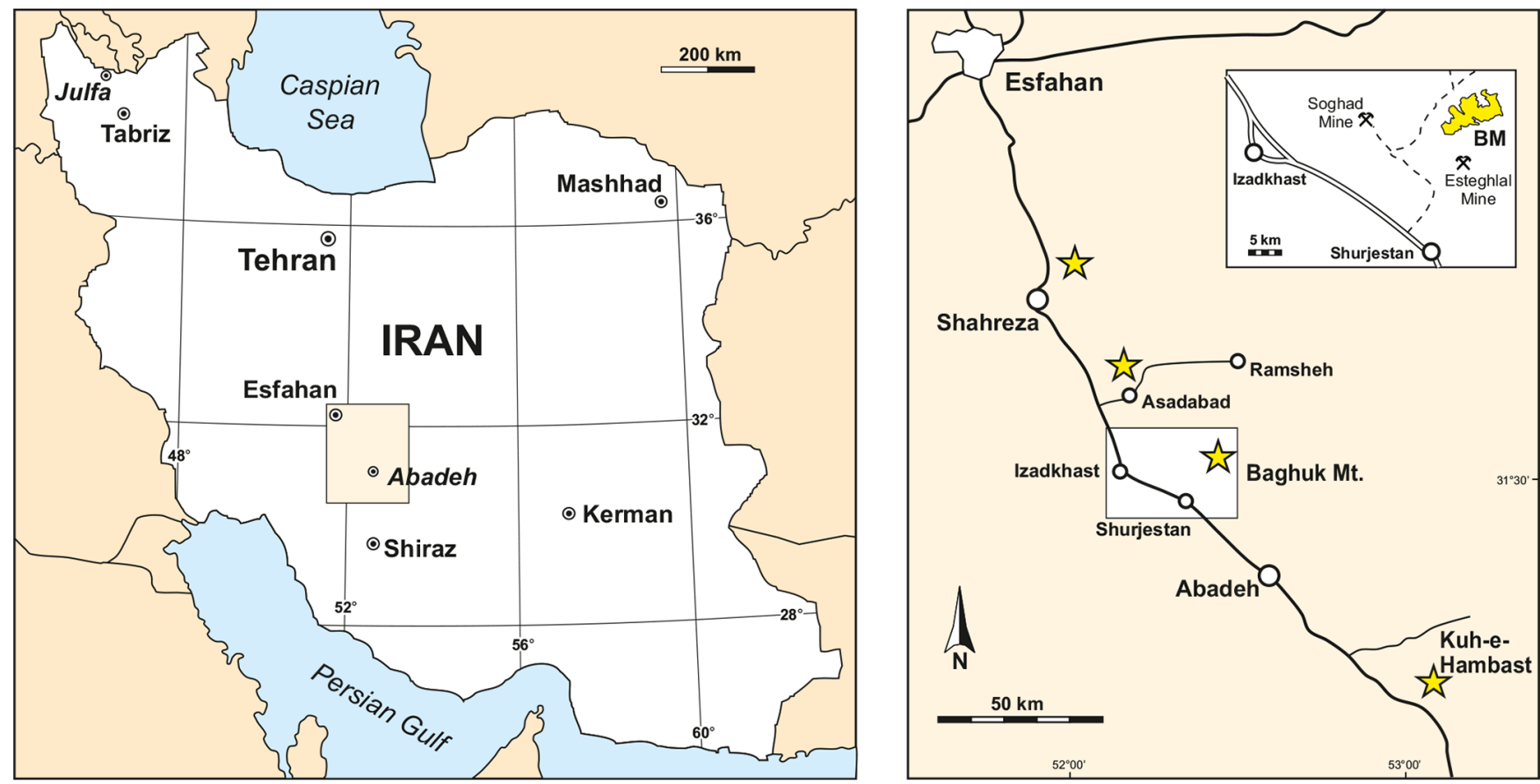

Figure 1. Geographic position of Permian-Triassic boundary sections, including Baghuk Mountain (BM), in Central Iran.

gion was located in a latitudinal position near the Equator (about $0^{\circ}$ for Shahreza and about $10^{\circ}$ for Abadeh) (Şengör, 1979; Muttoni et al., 2009).

Baghuk Mountain is located in Central Iran, $140 \mathrm{~km}$ SSE of Esfahan and $50 \mathrm{~km} \mathrm{NNW}$ of Abadeh (Fig. 1). We investigated and measured 10 parallel $\mathrm{P}-\mathrm{Tr}$ boundary sections; four of these (sections A, C, H and 1) were studied in detail with respect to their petrography and carbonate microfacies as well as their conodont, nautiloid and ammonoid content:

- Section A $\left(31.5635^{\circ} \mathrm{N}, 52.4376^{\circ} \mathrm{E}\right)$ is the complete Hambast Formation, Baghuk Member and basal $50 \mathrm{~m}$ of the Elikah Formation.

- Section B $\left(31.5633^{\circ} \mathrm{N}, 52.4398^{\circ} \mathrm{E}\right)$ is the lower $20 \mathrm{~m}$ of the Hambast Formation.

- Section J $\left(31.5649^{\circ} \mathrm{N}, 52.4410^{\circ} \mathrm{E}\right)$ is the Baghuk Member and lowest part of the Elikah Formation.

- Section E $\left(31.5664^{\circ} \mathrm{N}, 52.4428^{\circ} \mathrm{E}\right)$ is the upper $5 \mathrm{~m}$ of the Hambast Formation.

- Section $\mathrm{F}\left(31.5666^{\circ} \mathrm{N}, 52.4433^{\circ} \mathrm{E}\right)$ is the upper $5 \mathrm{~m}$ of the Hambast Formation.

- Section G $\left(31.5668^{\circ} \mathrm{N}, 52.4431^{\circ} \mathrm{E}\right)$ is the Baghuk Member and lowest part of the Elikah Formation.

- Section C $\left(31.5671^{\circ} \mathrm{N}, 52.4428^{\circ} \mathrm{E}\right)$ is the upper $5 \mathrm{~m}$ of the Hambast Formation, the Baghuk Member as well as the basal $40 \mathrm{~m}$ of the Elikah Formation.
- Section $\mathrm{H}\left(31.5670^{\circ} \mathrm{N}, 52.4435^{\circ} \mathrm{E}\right)$ is the upper $7 \mathrm{~m}$ of the Hambast Formation and Baghuk Member.

- Section $1\left(31.5675^{\circ} \mathrm{N}, 52.4436^{\circ} \mathrm{E}\right)$ is the upper $12 \mathrm{~m}$ of the Hambast Formation.

- Section K $\left(31.5926^{\circ} \mathrm{N}, 52.4389^{\circ} \mathrm{E}\right)$ is the Baghuk Member.

\section{Lithostratigraphy}

The Palaeozoic-Mesozoic transition in the Baghuk Mountain area (Fig. 3) is represented by a complete sedimentary succession without disconformities and possibly without gaps (Leda et al., 2014; Leda, 2020). All of the measured sections at Baghuk Mountain are very similar in their lithological succession. Except for the Baghuk Member, they show only minor variation in the thickness of individual rock units. They closely resemble the sections at Kuh-e-Hambast $(60 \mathrm{~km} \mathrm{SE}$ of Abadeh) and Shahreza (14.5 km NNE of Shahreza) (Baud et al., 1997; Besse et al., 1998; Gallet et al., 2000; Partoazar, 2002; Yazdi and Shirani, 2002; Kozur, 2004, 2005, 2007; Horacek et al., 2007; Richoz et al., 2010) (Fig. 4). The lithological units of the Permian-Triassic rock formations in the Abadeh region were refined by Taraz (1974) and Taraz et al. (1981), who identified seven lithological units for the Permian Surmaq, Abadeh and Hambast formations (units 1-7) and five for the Triassic Elikah Formation (units a-e) (Fig. 5).

In our study, particular attention has been paid to the Late Permian Hambast Formation (units 6 and 7 of Taraz et al., 


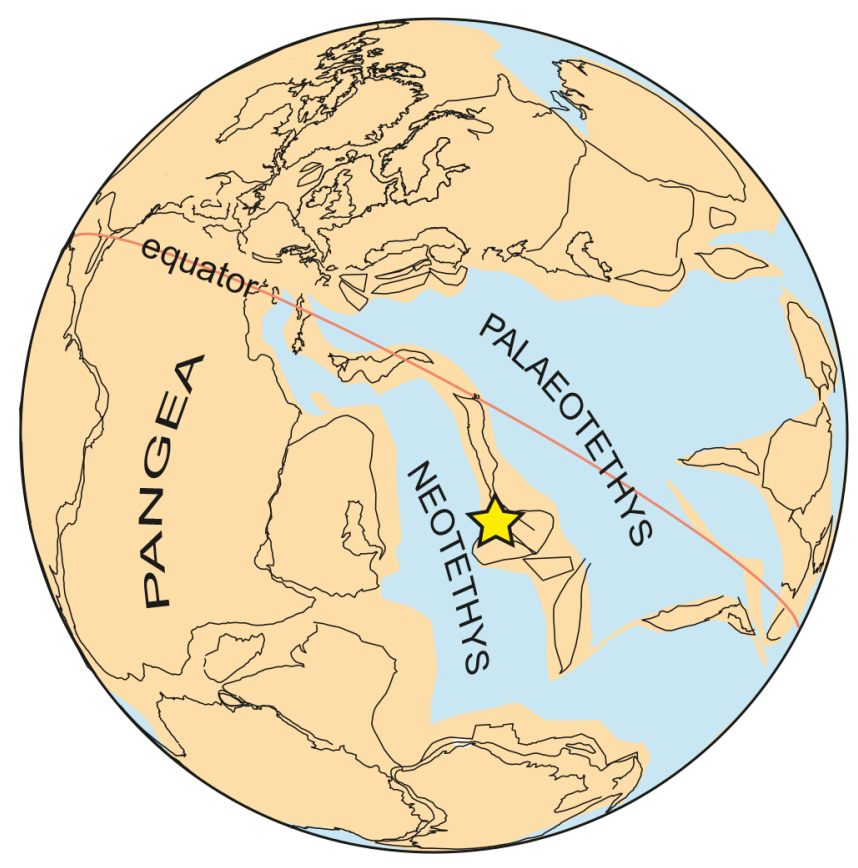

Figure 2. Palaeogeographic position of the Baghuk Mountain area during the Permian-Triassic boundary time interval (after Stampfli and Borel, 2002).

1981) and the Early Triassic Elikah Formation (unit a). We investigated the basal $20 \mathrm{~m}$ of the Elikah Formation, which includes a $2 \mathrm{~m}$ thick "Boundary Clay" (i.e. Baghuk Member) at its base.

We used the level of the main extinction pulse at the top of the Hambast Formation ("extinction horizon" is the base of the Baghuk Member; abbreviated EH) as the reference for the stratigraphic location of samples. This unequivocal reference horizon was used for the description of the precise position of the samples in the sections; it marks the $0 \mathrm{~m}$ level of our sections. In the following, the positions of samples are prefixed with a minus (-) for positions below and a plus $(+)$ for samples taken from above the reference horizon.

\subsection{Hambast Formation}

The Hambast Formation (34 m thick) is Wuchiapingian to Changhsingian in age. It shows the following succession (Fig. 6):

- A lower grey portion (16 m thick) is composed of marly shales and thin-bedded, dark-grey to light-grey, argillaceous lime mudstone with uneven bedding surfaces.

- A middle portion (13 m thick) consists of thin-bedded, red nodular limestone with few macrofossils. At the microscopic scale, it is an argillaceous lime mudstone and bioclastic wackestone with ammonoids, bivalves, ostracods, radiolarians and foraminifers.
- An upper part (5 m thick) can, at least partly, be correlated with the Paratirolites Limestone of the Julfa region (Ghaderi et al., 2014; Leda et al., 2014; Gliwa et al., 2020); it is late Changhsingian in age and yielded the ammonoid Paratirolites and closely related genera. It is composed of thin (up to $3 \mathrm{~cm}$ ) nodular limestone horizons, which alternate with very thin clay seams and form packages of $30 \mathrm{~cm}$ thickness. Only a few more compact limestone beds exist; the most conspicuous of these is a $10 \mathrm{~cm}$ thick, dark-red marly limestone bed, 3.25 to $4.00 \mathrm{~m}$ below the top of the Hambast Formation (Fig. 6). The base of the unit is defined the sharp lithological contrast defined by a purple shale intercalation with marly nodules containing the ammonoid Shevyrevites. The mass occurrence of the ammonoid genus Shevyrevites, which in the Julfa area occurs slightly below the Paratirolites Limestone (Korn et al., 2019; Gliwa et al., 2020), 5.00 to $5.70 \mathrm{~m}$ below the extinction horizon, can be seen as evidence for similar thicknesses of the interval yielding Paratirolites in the two regions.

The upper $2.65 \mathrm{~m}$ of the Hambast Formation comprises red, nodular, burrowed lime mudstone and wackestone with foraminifera, ostracods, radiolarians, brachiopods, bellerophontids and ammonoids. The characteristic features of this microfacies type are the breccia-like appearance as well as abundant fractures and stylolite seams. The matrix features are, besides micrite, some minor sparry cement and in situ recrystallization (neomorphic spar). Five centimetres below the top of the formation, a bedding surface shows a mass occurrence of small ammonoids of the genus Arasella (Fig. 7).

The top surface of the Hambast Formation with its sharp contact to the overlying Baghuk Member marks the endPermian mass extinction and is referred to as the "extinction horizon", as already postulated for the sections in the Hambast Range and near Shahreza (e.g. Korte et al., 2004a; Kozur, 2004). Like in these sections, the Baghuk Member at Baghuk Mountain is marked by a substantial decrease in fossil abundance (Leda et al., 2014).

In the Baghuk Mountain sections, the interface between the Hambast Formation and the Baghuk Member usually shows a sharp lithological contact, as known from the interface between the Paratirolites Limestone and the Aras Member in the Julfa region (Zakharov, 1992; Richoz et al., 2010; Ghaderi et al., 2014; Leda et al., 2014; Gliwa et al., 2020; Leda, 2020).

\subsection{Elikah Formation}

The Elikah Formation (Fig. 8), named Shahreza Formation by Heydari et al. (2008) for the occurrences in Central Iran, is close to $750 \mathrm{~m}$ thick (Horacek, 2007) and consists of two units of very different thicknesses: 


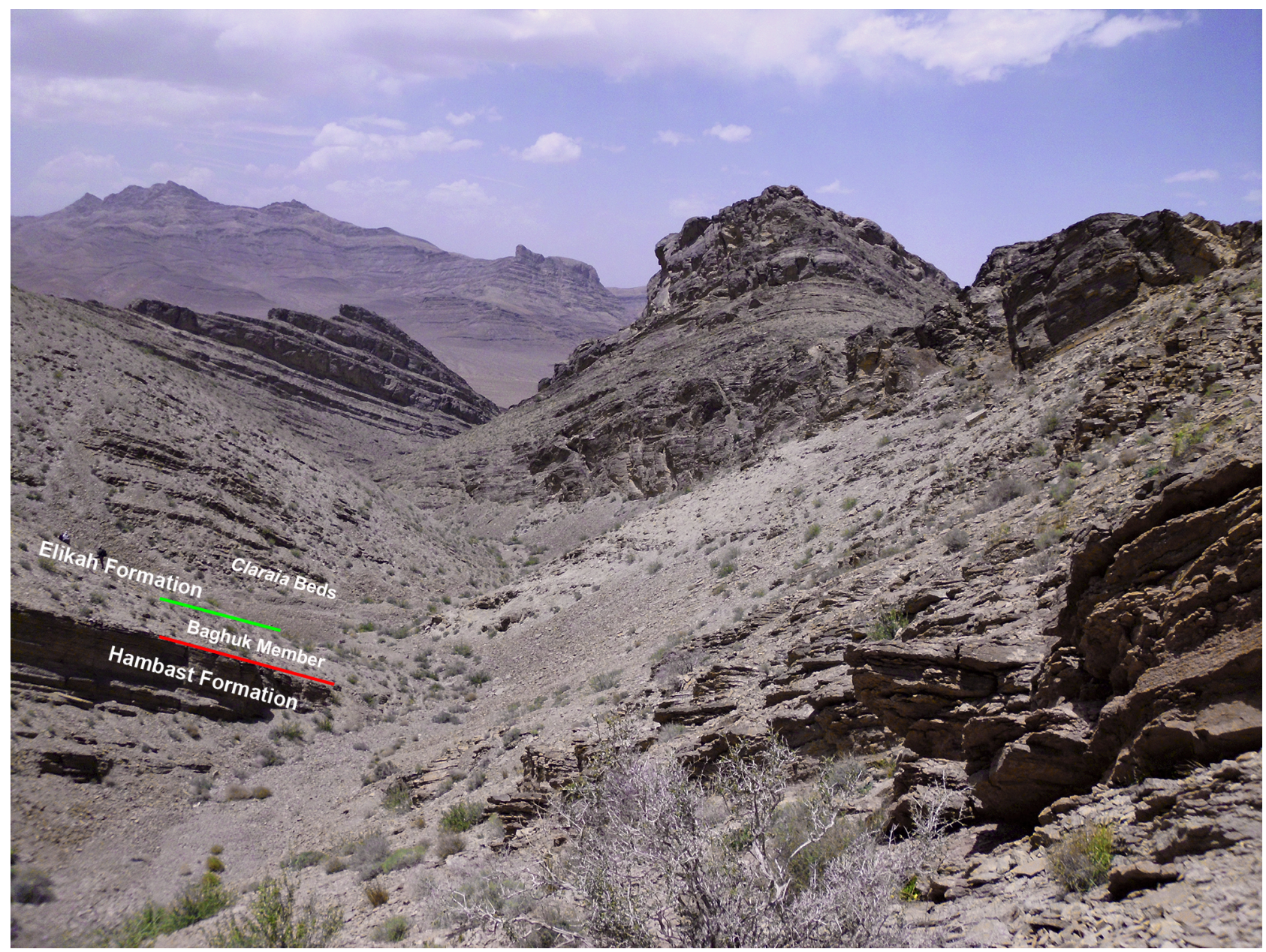

Figure 3. The Permian-Triassic boundary at Baghuk Mountain section C, Central Iran. View towards the north-west, in the background, summit composed of Triassic rocks.

- The "Boundary Clay" (renamed Baghuk Member here) is about $2 \mathrm{~m}$ thick (latest Changhsingian in age). It is separated from the Hambast Formation by a sharp contact between purple nodular limestone and dark-grey shales; it is made up of dark-grey to greenish shale with thin horizons of light-grey and light-pink marl and platy limestone (Fig. 9) and beds with "calcite fans". In section $\mathrm{C}$, a laterally restricted intercalation of very thin $(0.5-1 \mathrm{~cm})$ marly limestone nodules with small ammonoids occurs in the lowest part of the Baghuk Member (Fig. 10). Microscopically, the limestone nodules comprise lime mudstone with sponges, single ostracods, gastropods and calcimicrobe filaments. The matrix consists of microcrystalline spar and micrite intersected by abundant anastomosing stylolites. In the upper part of the Baghuk Member, grey, platy limestone beds of the Elikah Formation one or more enigmatic "calcite fan" layers occur, which form dome-shaped structures that resemble botryoids (Fig. 11). The "calcite fans" belong to in situ microbialite occurrence showing digitate up- ward growing branches. The correlation of five of the sections shows that the "calcite fan" layers are more frequent in sections with lower shale content (Fig. 9). These structures were, in the Hambast section, identified by Baud et al. (2021) as digitate stromatolites.

- The Claraia beds, Early Triassic in age are about $40 \mathrm{~m}$ thick at Baghuk Mountain. Their lowermost unit (about $1 \mathrm{~m}$ thick) is made up of grey, thin-bedded, platy and marly limestone. At the microscopic scale, it is a densely laminated bindstone with peloids, cortoids and sparite-filled voids. Higher in the section, alternations of light-grey shale, thin beds of pale-grey marl and solid limestone beds characterize the following $17 \mathrm{~m}$ of the Elikah Formation. Small pyrite nodules occur occasionally in thin black shale horizons at +4.40 and $+5.25 \mathrm{~m}$. A number of thin-bedded marls and shales contain abundant specimens of Claraia. Apart from abundant thin-shelled bivalves, the fossil inventory of this interval consists of gastropods, ostracods, foraminifers and 


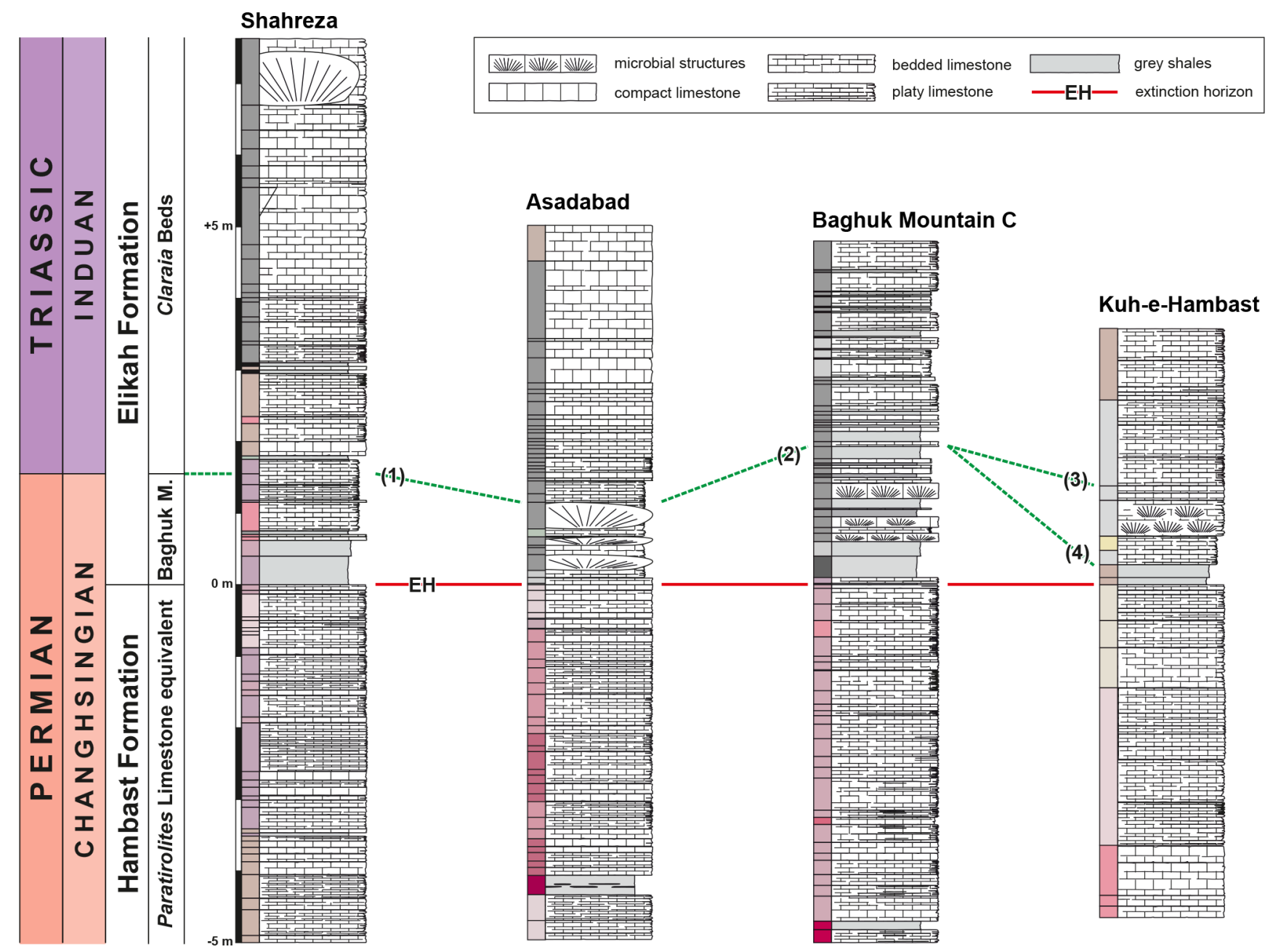

Figure 4. Correlation of the Permian-Triassic boundary beds in Central Iranian sections. Kuh-e-Hambast rock column after Kozur (2005). Position of the conodont-based Permian-Triassic boundary after Kozur (2005; 1, 3), Farshid et al. (2016; 2) and Richoz et al. (2010; 4). Asadabad section after unpublished data.

ammonoids. The platy and marly limestone beds possess a recrystallized texture, suggesting microspar cementation and in situ recrystallization. The petrographic investigation of the carbonate allows distinction of several microfacies types according to fabrics and bioclast occurrences (Heuer et al., 2021).

The basal $20 \mathrm{~m}$ of the Elikah Formation (Fig. 12) shows cyclic sedimentation with passages mainly composed of marly shales and thin-bedded marls and limestones (1$2 \mathrm{~cm}$ bed thickness) and passages composed of rather pure, medium-bedded limestones $(10-15 \mathrm{~cm})$. The evaluation of bed thickness visualizes three peaks in bed thickness, i.e. two in the Baghuk Member (caused by the calcite fan beds) and one at $+19.70 \mathrm{~m}$ (caused by a $20 \mathrm{~cm}$ thick microbialite bed). Between these, there is a succession of alternating thinbedded and thick-bedded units.

Horizons with microbial buildups occur in the Baghuk Member and in the Claraia beds between +7.00 to
$+10.00 \mathrm{~m}$, at $+13.50 \mathrm{~m}$ and at +19.70 . Very similar are the occurrences of bivalves (Claraia, Pseudomonotis), which are particularly frequently at +8.00 to $+10.00 \mathrm{~m},+13.00$ to $+13.50 \mathrm{~m},+14.50$ to $+15.50 \mathrm{~m}$ and +19.50 to $+19.70 \mathrm{~m}$. Most of the bivalve shells are convex-up oriented; however, in two horizons $(+8.70,+15.50 \mathrm{~m})$ they are mixed convexup and convex-down and serve as evidence for tempestite sedimentation.

\section{Conodont stratigraphy}

Conodonts were studied in section 1 (up to extinction horizon) and section A (above the extinction horizon). For the investigation of the conodont succession, a total of 200 samples, ranging in size from 3 to $5 \mathrm{~kg}$, were processed according to the standard protocol. The samples were dissolved in a buffered solution of $10 \%$ acetic acid using standard methods. The smallest sieve size was $15.6 \mu \mathrm{m}$, and each residue was 


\begin{tabular}{|c|c|c|c|c|c|}
\hline \multirow{5}{*}{ 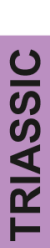 } & \multirow{5}{*}{$\begin{array}{l}z \\
4 \\
2 \\
0 \\
z \\
-\end{array}$} & Conodont zones NW Iran & Conodont zones Baghuk Mt. & \multicolumn{2}{|c|}{ Lithostratigraphy } \\
\hline & & Isarcicella isarcica & Isarcicella isarcica & \multirow{6}{*}{ 동 $\frac{\text { 음 }}{\frac{1}{\pi}}$} & \multirow{4}{*}{ Claraia Beds } \\
\hline & & Isarcicella staeschei & \multirow[t]{2}{*}{ Isarcicella staeschei } & & \\
\hline & & Hindeodus lobatus & & & \\
\hline & & Hindeodus parvus & Hindeodus parvus & & \\
\hline \multirow{11}{*}{$\begin{array}{l}z \\
\frac{Z}{\Sigma} \\
\frac{1}{\alpha} \\
\mathbf{\alpha}\end{array}$} & \multirow{10}{*}{$\begin{array}{l}Z \\
\frac{Z}{0} \\
0 \\
\frac{Z}{0} \\
0 \\
\frac{1}{0} \\
Z \\
\frac{1}{1} \\
\frac{1}{0}\end{array}$} & M. ultima - S. ?mostleri & \multirow{2}{*}{ barren interval } & & \multirow{2}{*}{$\begin{array}{l}\text { Baghuk Member } \\
\text { ("Boundary Clay") }\end{array}$} \\
\hline & & H. praeparvus - $H$. changxingensis & & & \\
\hline & & Clarkina hauschkei & Clarkina hauschkei & \multirow{9}{*}{ 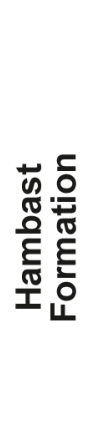 } & \multirow{9}{*}{$\begin{array}{l}\text { Paratirolites } \\
\text { Limestone } \\
\text { equivalent }\end{array}$} \\
\hline & & Clarkina abadehensis & Clarkina abadehensis & & \\
\hline & & Clarkina yini & Clarkina yini & & \\
\hline & & Clarkina nodosa & Clarkina nodosa & & \\
\hline & & Clarkina bachmanni & Clarkina bachmanni & & \\
\hline & & Clarkina chanxingensis & Clarkina chanxingensis & & \\
\hline & & Clarkina subcarinata & Clarkina subcarinata & & \\
\hline & & C. orientalis - C. subcarinata int. & no index conodonts & & \\
\hline & 3 & Clarkina orientalis & Clarkina orientalis & & \\
\hline
\end{tabular}

Figure 5. Stratigraphic subdivision of the Permian-Triassic boundary sections in the Julfa sections (from Ghaderi et al., 2014) and at Baghuk Mountain (from Farshid et al., 2016) with lithostratigraphic correlation. W - Wuchiapingian.

hand-picked in its entirety without using heavy liquid separation techniques. Illustrated specimens were gold-palladium coated, prior to SEM microphotography.

The conodonts are suitable for a correlation of distant regions, such as Transcaucasia and Central Iran (Kozur, 2004, 2005, 2007; Henderson et al., 2008; Shen and Mei, 2010; Horacek et al., 2021). Kozur $(2005,2007)$ sampled the Hambast section and distinguished 10 Changhsingian conodont biozones (Clarkina hambastensis to Merrillina ultima-Stepanovites? mostleri zones) and two Early Triassic conodont biozones (Hindeodus parvus and Isarcicella isarcica zones). Ghaderi (2014) and Ghaderi et al. (2014) investigated the sections in the Julfa area (NW Iran) and achieved fine resolution by bed-by-bed sampling. Their revision of the biostratigraphy led to the separation of four conodont zones for the Griesbachian substage (from bottom to top Hindeodus parvus, H. lobota, Isarcicella staeschei and I. isarcica zones) (Fig. 13).

A biostratigraphic subdivision of the Baghuk Mountain sections using conodonts was established by Farshid et al. (2016). They established seven conodont zones (Fig. 14) for the Changhsingian sections (from bottom to top the Clarkina subcarinata, $C$. changxingensis, $C$. bachmanni, $C$. nodosa, C. yini, C. abadehensis, C. hauschkei zones) and two conodont biozones for the Griesbachian successions (in ascending order the $H$. parvus and the Isarcicella isarcica zones). Index conodonts of the Clarkina orientalis-C. subcarinata Zone were not traced within the collected material from Baghuk Mountain. Instead, Hindeodus julfensis occurs with the last occurrence datum (LOD) of $C$. orientalis in a sample at $-8.90 \mathrm{~m}$. Most probably, the Wuchiapingian-
Changhsingian boundary lies within an interval between -8.90 and $-8.00 \mathrm{~m}$. The highest recorded Permian taxon is C. cf. hauschkei, which has a first occurrence datum $0.02 \mathrm{~m}$ below the extinction horizon, probably marking the base of the $C$. hauschkei Zone.

Unfortunately, neither the $H$. praeparvus $-H$. changxingensis nor the Merrillina ultima-Stepanovites? mostleri zones were traced in the Baghuk Mountain sections, since the samples from the Baghuk Member interval were unproductive. The first appearance of Hindeodus parvus is a tool to correlate with the adopted Permian-Triassic boundary GSSP. However, there is a problem with the precise position of the $\mathrm{P}-\mathrm{Tr}$ boundary, because the first occurrence of $H$. parvus is in sample $+1.85 \mathrm{~m}$, although this is based solely on a broken element. Well-preserved $H$. parvus (actually $H$. parvus erectus) platform elements come from sample $+2.00 \mathrm{~m}$. Is arcicella isarcica occurs first in sample $+3.71 \mathrm{~m}$, defining the base of the I. isarcica Zone. Hindeodus lobota was not found in the Baghuk Mountain sections. Isarcicella staeschei was found but co-occurs with Isarcicella isarcica.

The lack of conodonts in the Baghuk Member is the reason why the Baghuk Mountain sections cannot help to solve the problems with the entry of Hindeodus parvus in the Central Iranian sections. For Kuh-e-Hambast, for instance, there are two competitive interpretations (discussed in detail by Horacek et al., 2021): some working groups (Taraz et al., 1981; Gallet et al., 2000; Horacek et al., 2007; Richoz et al., 2010) drew the boundary at $0.30 \mathrm{~m}$ above the extinction horizon (and thus at the base of the beds with the microbial buildups), while $\operatorname{Kozur}(2005,2007)$ drew the boundary higher at a position $1.40 \mathrm{~m}$ above the extinction horizon (and thus above 


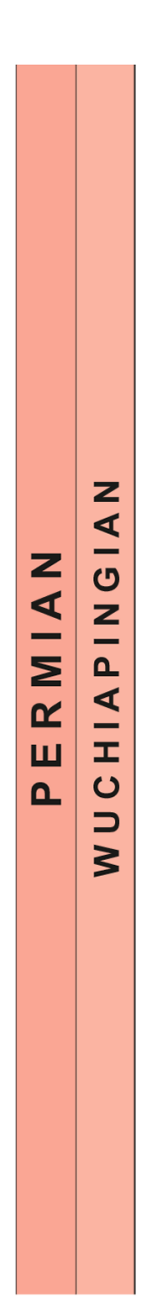

BM B section

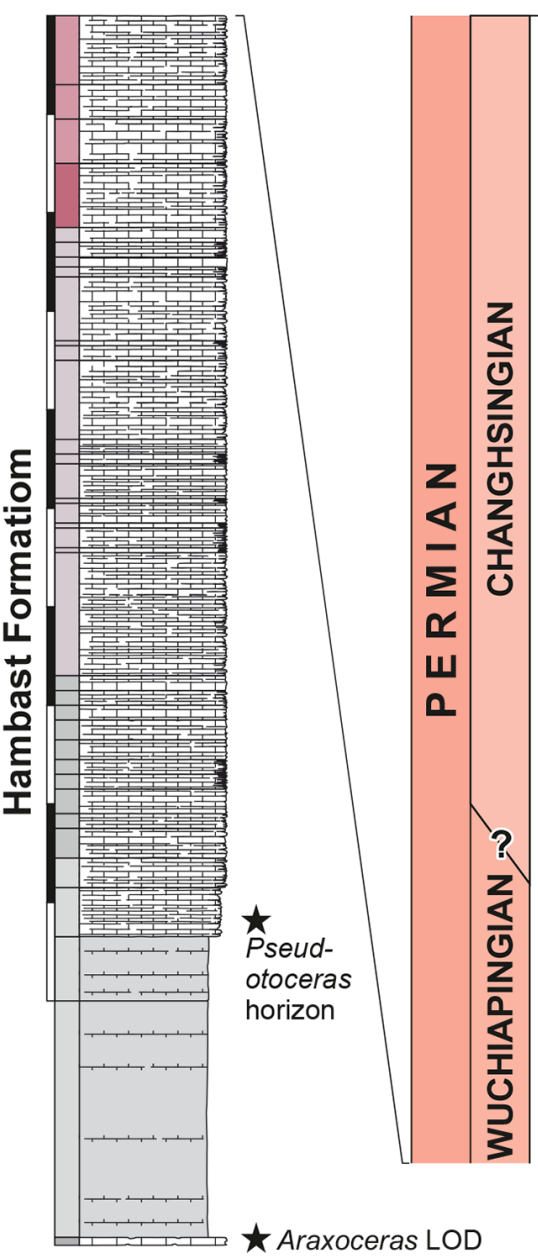

BM 1 section BM C section BM H section

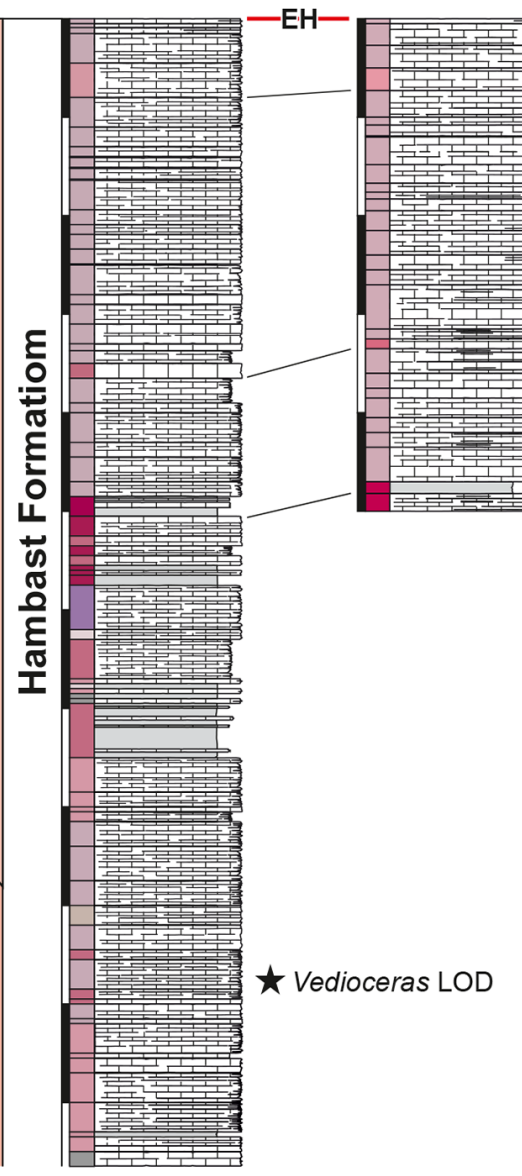

\Arasella

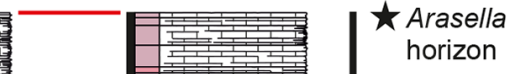

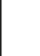

Paratirolites

Limestone

equivalent

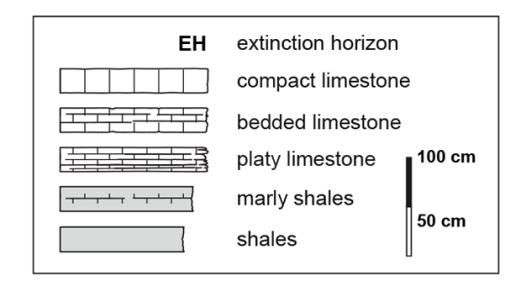

Figure 6. Columnar section of the Hambast Formation at Baghuk Mountain with correlation of the most important index horizons.

the lowest "calcite fan" beds). An occurrence of Hindeodus parvus below the "calcite fans" at Hambast may speak for an Early Triassic age of the upper part of the Baghuk Member at Baghuk Mountain.

\section{Ammonoid stratigraphy}

The Baghuk Mountain sections yielded rather well-preserved early Wuchiapingian to late Changhsingian ammonoid assemblages (Fig. 15 for some Wuchiapingian representatives). Ammonoid assemblages occur throughout the Hambast formation, but they are very rare and poorly preserved in the Baghuk Member. Ammonoids occur occasionally with rather poor preservation in some levels of the Elikah Formation at +20.50 and $+24.05 \mathrm{~m}$. The study of the new material will show that the ammonoid succession, as proposed by Bando (1979) and Taraz et al. (1981) for the Hambast range, requires revision. A co-occurrence of the genera Araxoceras (a characteristic early Wuchiapingian genus) and Paratiro- lites (a characteristic late Changhsingian genus), for instance, is very unlikely and cannot be confirmed by the study of the Baghuk Mountain section. Zakharov et al. (2010) discussed the ammonoid occurrences of the Hambast Range and provided very precise data on the occurrence of various species within the Wuchiapingian part of the section. However, they also proposed co-occurrences of Araxoceras and Vedioceras, which are not known from the Julfa region (Shevyrev, 1965).

It is obvious that the ammonoid succession at Baghuk Mountain closely resembles the succession in Transcaucasia and NW Iran (Ruzhencev and Shevyrev, 1965; Shevyrev, 1965; Ghaderi et al., 2014; Korn et al., 2016, 2019; Gliwa et al., 2020). In ascending order, seven major assemblages can be separated, of which the first six are of Late Permian age:

1. Beds with Araxoceras. Dark-grey limestone beds with uneven bedding surfaces at the base of the Hambast Formation contain numerous ammonoids of various genera including Araxoceras and Vescotoceras. The occurrence is probably time equivalent to the Araxoceras- 


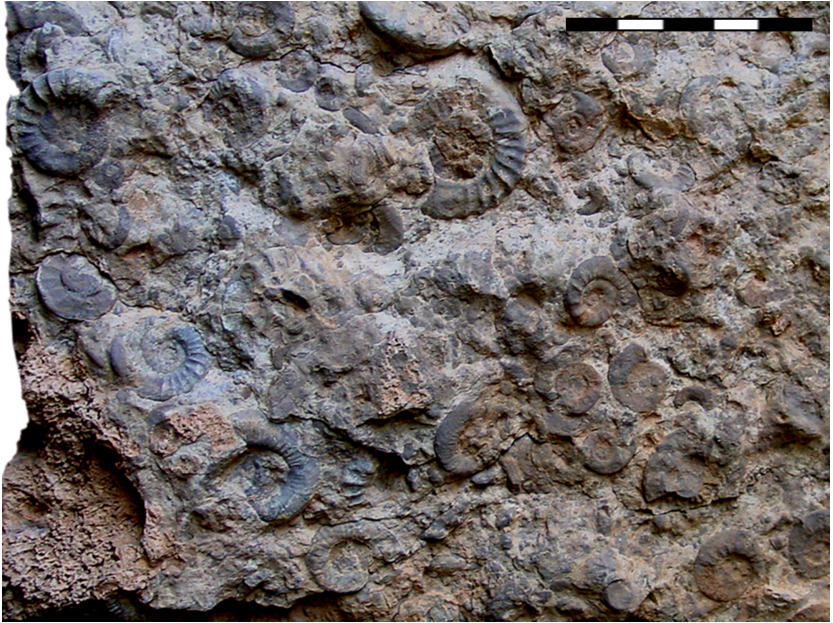

Figure 7. Slab of a marly limestone within the uppermost part of the Hambast Formation with many small ammonoids of the genus Arasella. Baghuk Mountain C section, lower view of the bedding plane at $-0.05 \mathrm{~m}$. Scale bar units $=10 \mathrm{~mm}$.

bearing beds at Kuh-e-Hambast described by Zakharov et al. (2010).

2. Beds with Pseudotoceras. Pseudotoceras is common in a light-grey platy limestone interval above the Araxoceras horizon.

3. Beds with Vedioceras. Vedioceras is very common in pink nodular limestone in the middle portion of the Hambast Formation. The stratigraphically highest occurrence of a specimen of Vedioceras (i.e. the highest occurrence of a characteristic Wuchiapingian ammonoid) is at a level $9.90 \mathrm{~m}$ below the extinction horizon. This occurrence coincides with the situation in the Dzhulfa and Julfa sections, where Vedioceras has a position separated from occurrences of Araxoceras (Ruzhencev, 1959, 1962, 1963; Shevyrev, 1965, 1968; Korn and Ghaderi, 2019).

4. Beds with Shevyrevites and Dzhulfites. Shevyrevites has a mass occurrence in a thin interval about $5 \mathrm{~m}$ below the extinction horizon. All sections at Baghuk Mountain show a conspicuous red shale horizon accompanied by nodular platy limestone with numerous ammonoids, mostly Shevyrevites shevyrevi, on the bedding planes. The time-equivalent horizon in the sections near Dzhulfa and Julfa has a position in the upper portion of the predominantly argillaceous Zal Member of the Julfa Formation (Ruzhencev and Shevyrev, 1965; Korn et al., 2019).

5. Beds with Paratirolites, Alibashites and Abichites. The top $4-5 \mathrm{~m}$ of the Hambast Formation is equivalent to the Paratirolites Limestone of the sections in the Julfa region (Ghaderi et al., 2014; Korn et al., 2016; Gliwa et

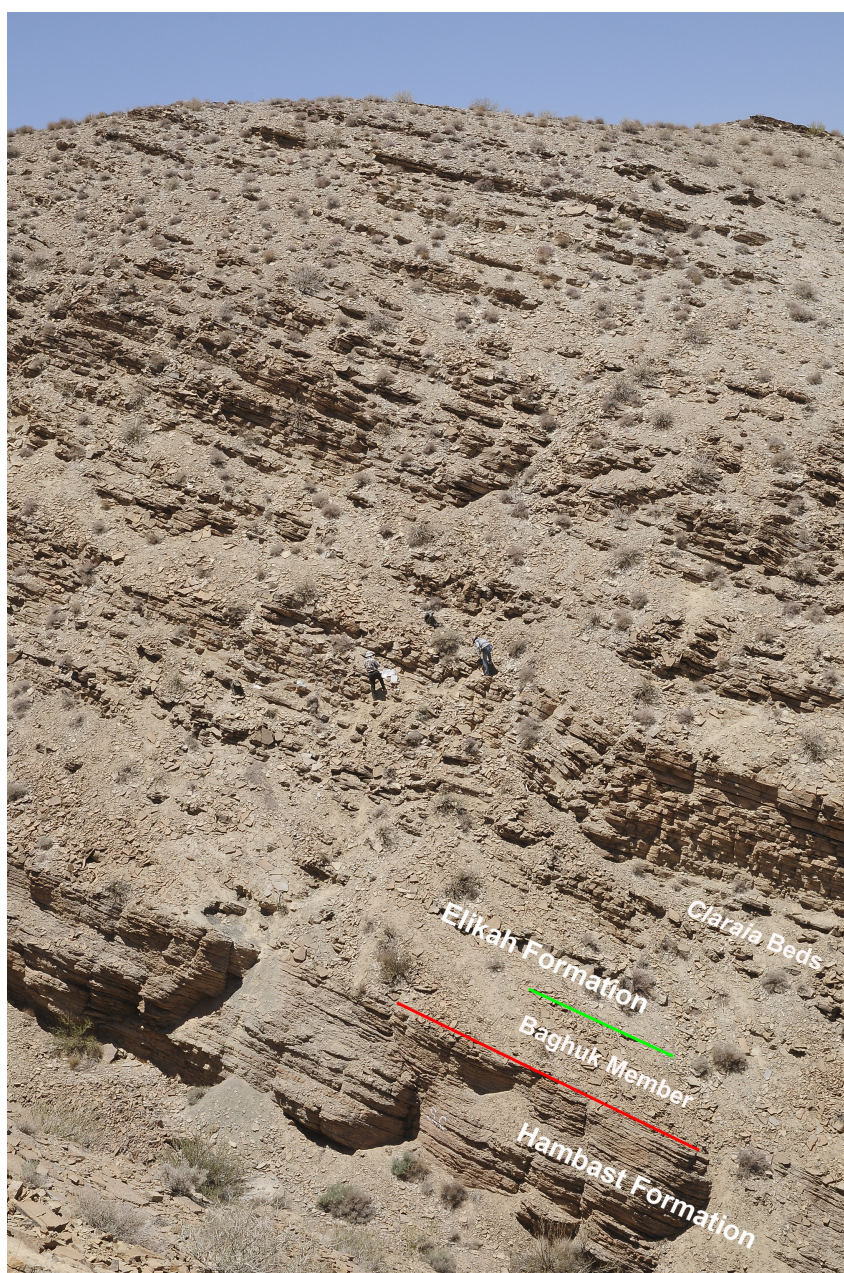

Figure 8. Section $\mathrm{C}$ with the top part of the Hambast Formation and the basal $40 \mathrm{~m}$ of the Elikah Formation including the Baghuk Member. View towards the west.

al., 2020). Like near Julfa, these beds show a succession of ammonoid species, which allow separation of distinct ammonoid zones and diversity dynamics (Kiessling et al., 2018). A succession of assemblages with the separation of distinct ammonoid zones can be recorded; the assemblages are composed of the genera Pseudogastrioceras, Dzhulfites, Paratirolites, Alibashites, Abichites, Stoyanowites and Arasella as well as new, yet undescribed genera (Korn et al., 2021).

The ammonoids of this interval are rarely preserved with shell; they are almost entirely preserved as internal moulds, of which the lower side is better preserved (Fig. 16). The ammonoid specimens occur scattered in the rock succession, and only some beds show concentrations. Only one bedding plane at $-0.04 \mathrm{~m}$ shows mass occurrences of small specimens, preferably of Arasella (Fig. 7). 


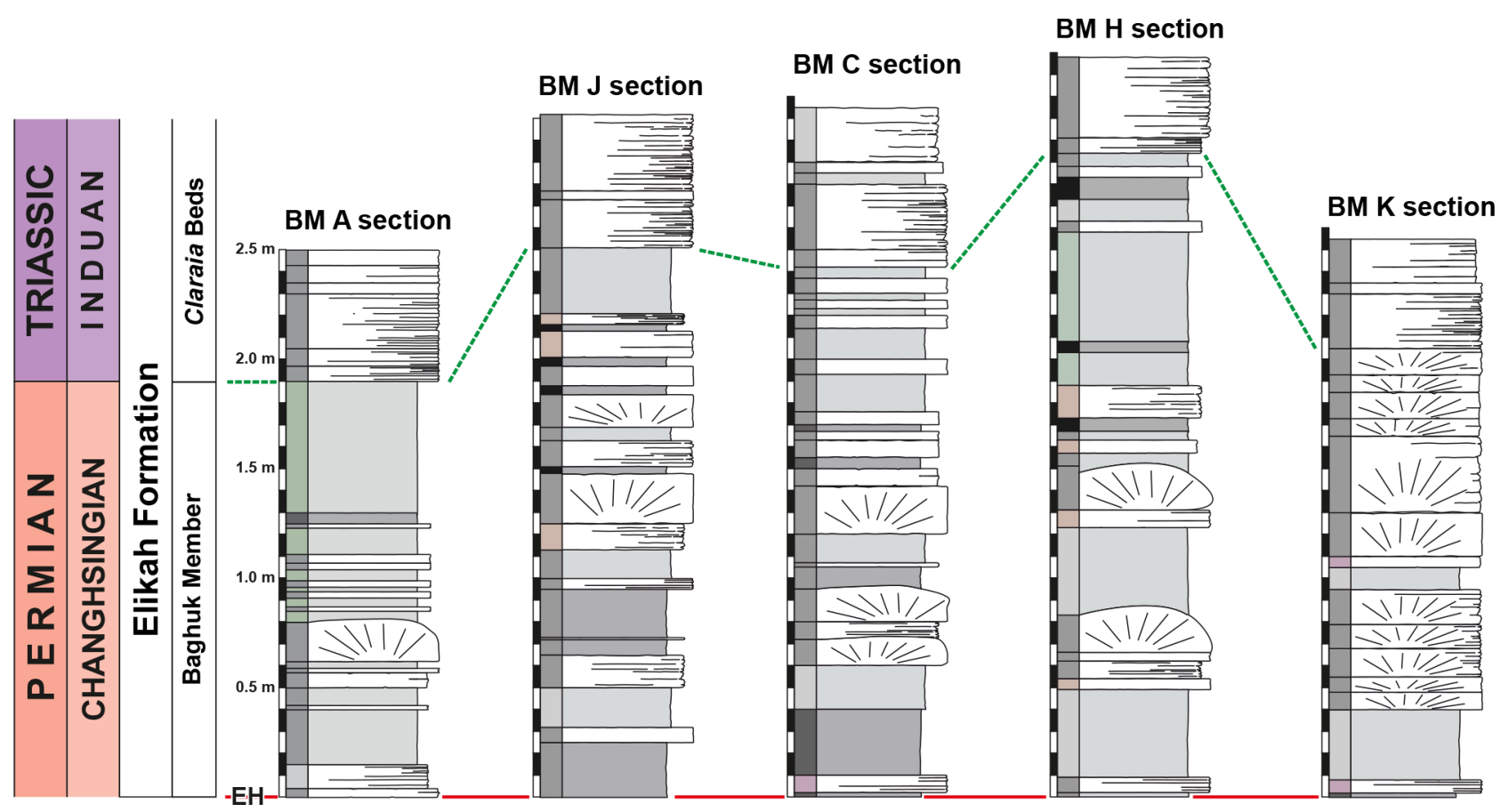

Figure 9. Columnar sections of the Baghuk Member ("Boundary Clay") in some of the sections at Baghuk Mountain. Legend as in Figs. 4 and 6; EH - extinction horizon.

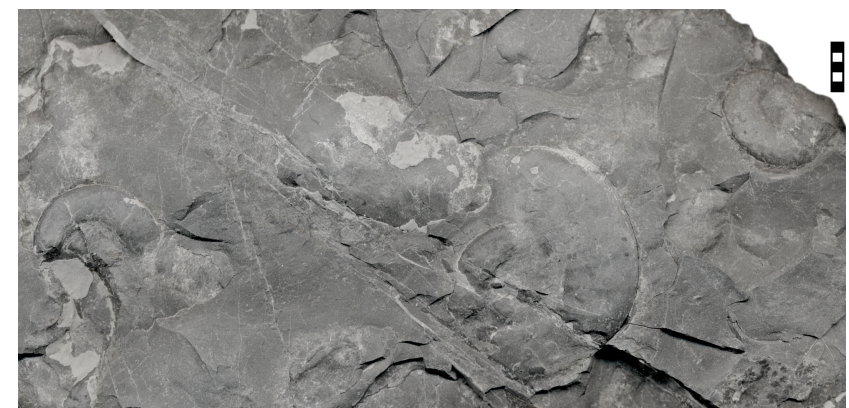

Figure 10. Slab of a marly shale within the lowermost part of the Baghuk Member with small ammonoids (possibly Arasella sp.). Baghuk Mountain C section, at $+0.05 \mathrm{~m}$. Scale bar units $=10 \mathrm{~mm}$.

6. Baghuk Member with extremely sparse ammonoids. Only a few crushed ammonoid specimens were collected from the basal nodular limestone intercalations in the Baghuk Member (Fig. 10). They may belong to the genus Arasella, but the poor preservation does not allow a clear identification.

7. Claraia beds with Early Triassic ammonoids. In the lowermost $25 \mathrm{~m}$ of the Elikah Formation, ammonoids occur occasionally in very poor preservation. The assemblage is similar, both in composition and preservation, to the one from Abadeh described by Bando (1981). These can only be clearly identified to the family level as belonging to Ophiceratidae, possibly

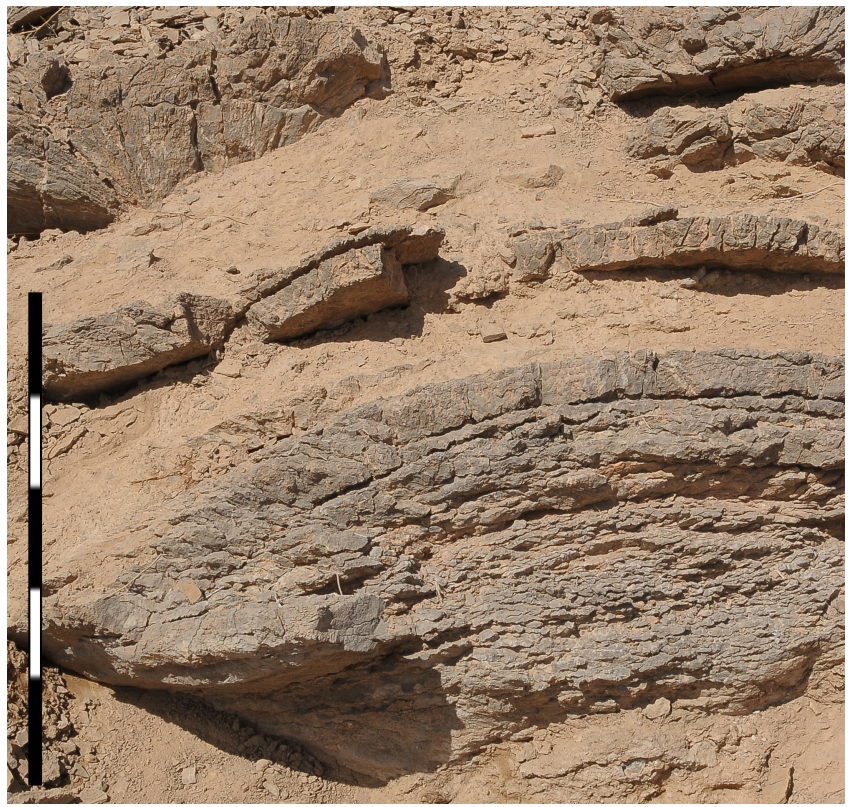

Figure 11. Field photograph of in situ microbialite occurrence showing digitate upward growing branches of digitate stromatolite columns in the Baghuk Member; Baghuk Mountain K section. Scale bar units $=10 \mathrm{~cm}$. 

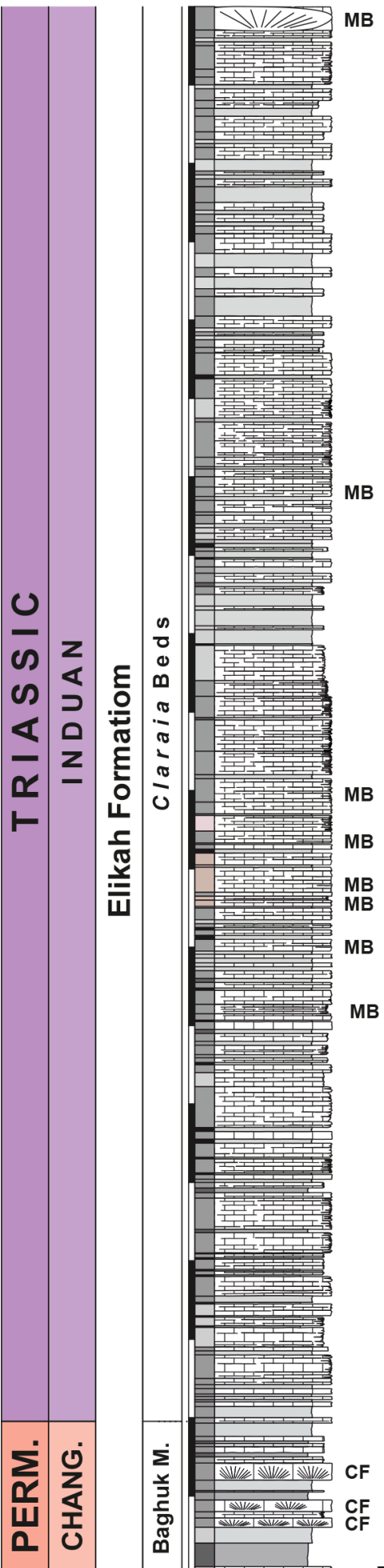

B mean bed thickness

$\begin{array}{llllllll}0 & 2 & 4 & 6 & 8 & 10 & 12\end{array}$
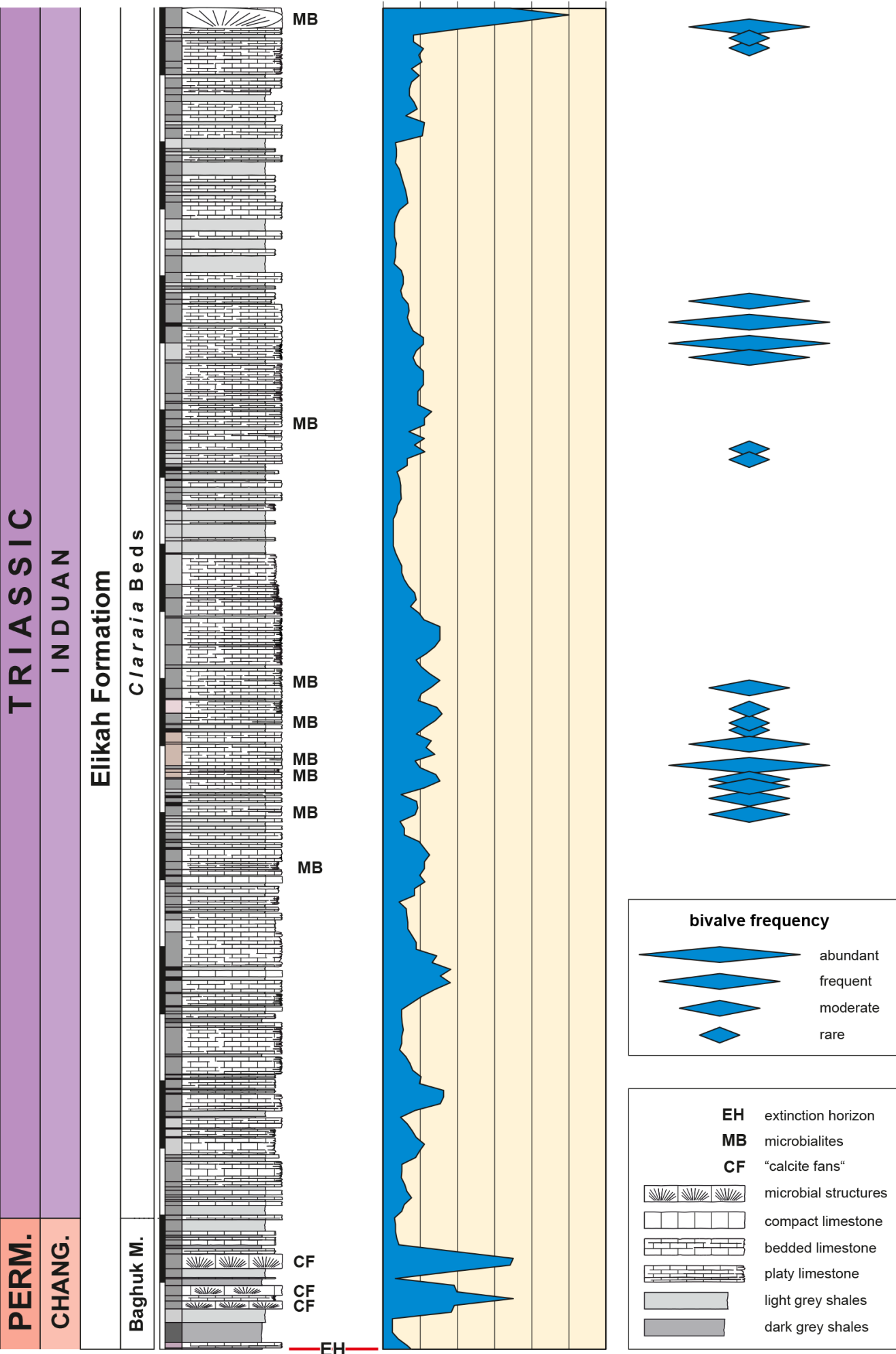

Figure 12. Columnar section of the basal part of the Elikah Formation at Baghuk Mountain with the position of microbial buildups, changes in bed thickness and frequency of bivalve shells. 


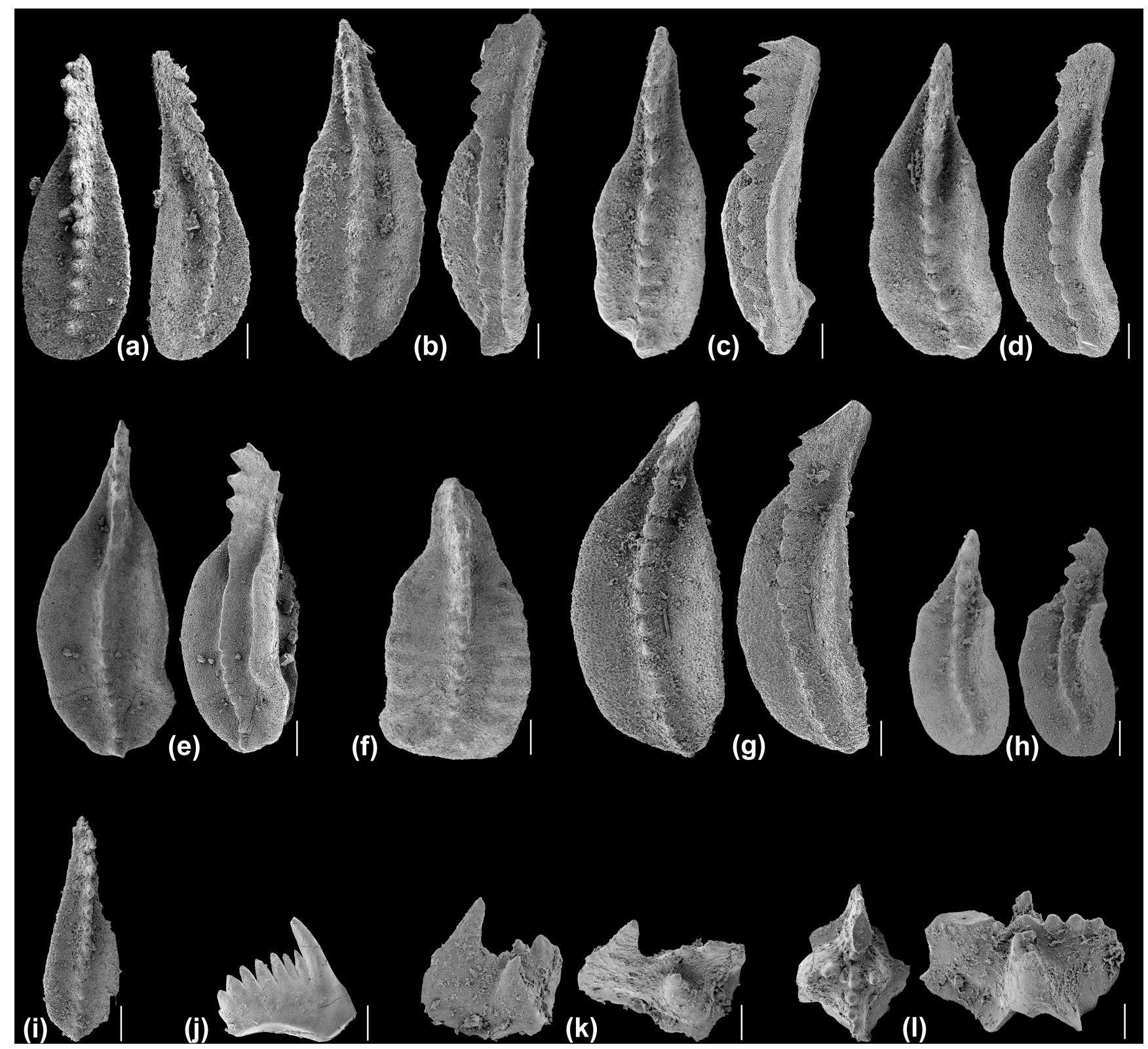

Figure 13. Characteristic conodonts from Baghuk Mountain section A (scale bars $=100 \mu \mathrm{m}$ ), oral and oblique views; all specimens stored in the collection of the Islamic Azad University, Tehran North Branch (IAUTNB). (a) Clarkina orientalis (Barskov and Koroleva, 1970), specimen IAUTNB\#115; -8.90 m. (b) Clarkina subcarinata (Sweet in Teichert et al., 1973), specimen IAUTNB\#137; -7.50 m. (c) Clarkina changxingensis (Wang and Wang, 1981), specimen IAUTNB\#142; $-5.00 \mathrm{~m}$. (d) Clarkina deflecta (Wang and Wang, 1981), IAUTNB\#189; -2.50 m. (e) Clarkina bachmanni Kozur, 2004, specimen IAUTNB\#162; -3.90 m. (f) Clarkina nodosa Kozur, 2004, specimen IAUTNB\#203; -2.20 m. (g) Clarkina yini Mei in Mei et al., 1998, specimen IAUTNB\#215; -1.95 m. (h) Clarkina abadehensis Kozur, 2004 specimen IAUTNB\#231; -0.25 m. (i) Clarkina hauschkei Kozur, 2004, specimen IAUTNB\#250; -0.05 m. (j) Hindeodus parvus (Kozur and Pjatakova, 1976), specimen IAUTNB\#251; +2.15 m. (k) Isarcicella staeschei Dai and Zhang, 1989, specimen IAUTNB\#265; +3.75 m. (l) Isarcicella isarcica (Huckriede, 1958), specimen IAUTNB\#264; +3.75 m.

Ophiceras and Vishnuites, but any reliable identification is hampered by their poor preservation. These, however, would tend to indicate a late Griesbachian age. Higher up, ammonoids are rarer, but two horizons (at +20.50 and $+24.05 \mathrm{~m}$ ) yielded a new undocumented and de- cently preserved ammonoid fauna. They are identifiable at genus or species level. Both yielded monospecific assemblages, the lower with Gyronites cf. dubius (von Krafft, 1909) and the upper with Ussuridiscus varaha 


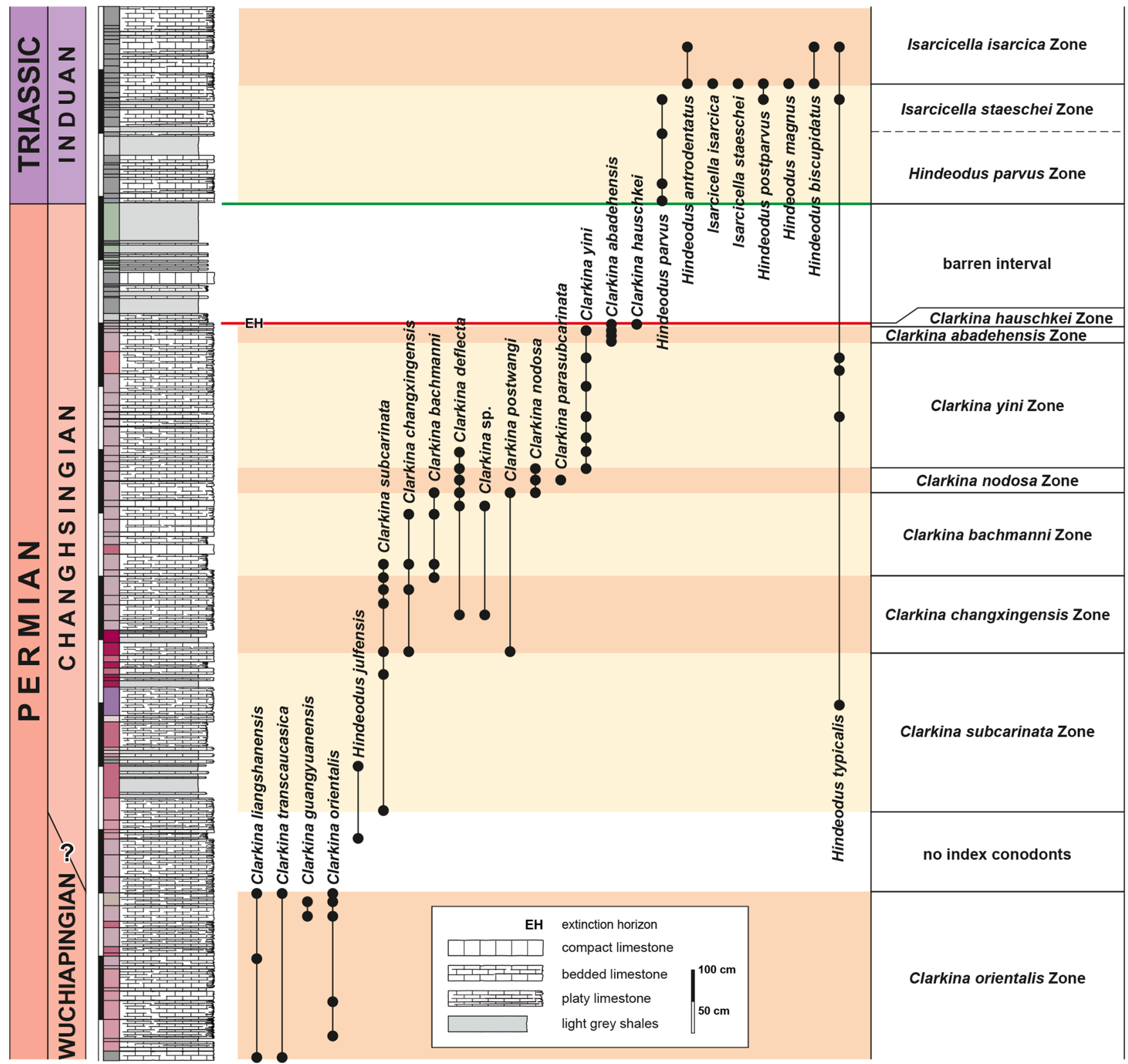

Figure 14. Succession of conodont species and zones at Baghuk Mountain; combination of Baghuk Mountain sections 1 (up to the extinction horizon) and Baghuk Mountain section A (above the extinction horizon). ChZ-Clarkina hauschkei Zone. (after Farshid et al., 2016).

(Diener, 1895). These species give an early Dienerian age for the horizons.

Besides the time-equivalent Chinese occurrences and the occurrences of Julfa (NW Iran), the ammonoid material from Baghuk Mountain is the most diverse assemblage known from the critical interval before the end-Permian mass extinction. In total, about 50 Wuchiapingian and Changhsingian ammonoid species have been recorded at Baghuk Mountain so far. A monographic description of the Changhsingian am- monoids from Baghuk Mountain has been submitted (Korn et al., 2021).

\section{Nautiloid succession}

Sections at Baghuk Mountain provided Late Permian nautiloids mainly from the early and late Wuchiapingian strata (Fig. 17), while the Changhsingian material is poor. There are about 20 Wuchiapingian species identified by us; they belong to the families Koninckioceratidae, Tainoceratidae, 

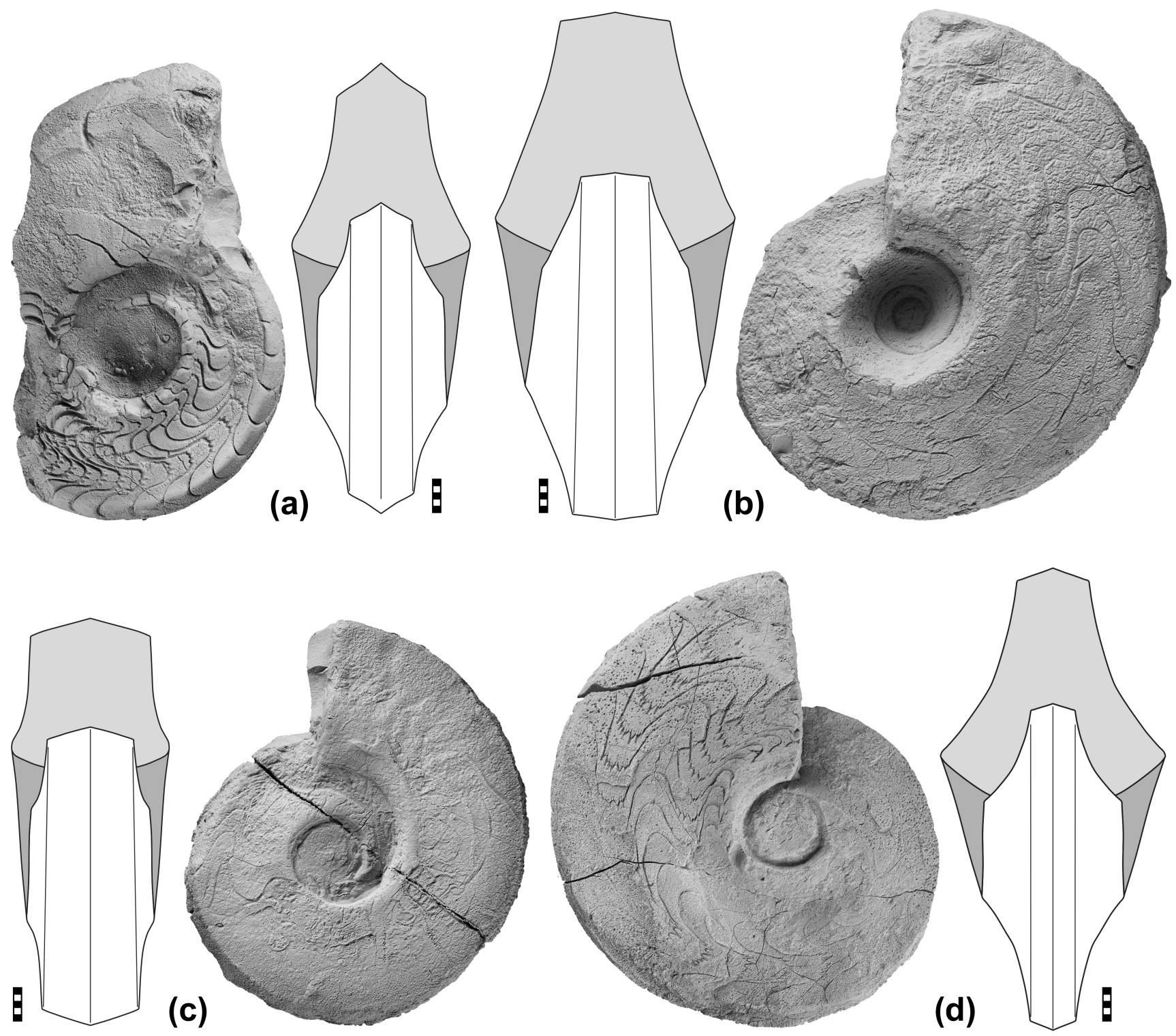

Figure 15. Selected Wuchiapingian representatives of ammonoids from Baghuk Mountain; all specimens stored in the collection of the Museum für Naturkunde, Berlin. (a) Prototoceras sp., specimen MB.C.30219 (Araxoceras beds). (b) Vedioceras sp., specimen MB.C.30220 (Vedioceras beds). (c) Eoaraxoceras sp., specimen MB.C.30221 (Araxoceras beds). (d) Urartoceras sp., specimen MB.C.30222 (Pseudotoceras beds). Scale bar units $=1 \mathrm{~mm}$.

Grypoceratidae and Liroceratidae. With this richness of species, the Baghuk Mountain assemblages rank among the top four worldwide (together with the Salt Range, the Transcaucasia-NW Iran region and southern China).

Although the identification has not been completed and the monographic description is still premature, it can be said that the Wuchiapingian material represents two assemblages that differ in their taxonomic composition:

1. In the early Wuchiapingian (Araxoceras ammonoid assemblage), dominant are representatives of the family Liroceratidae (Liroceras, Permonautilus), accompanied by rarer Grypoceratidae (Domatoceras) and Tainoceratidae (Tainoceras, Tirolonautilus).

2. In the late Wuchiapingian (Vedioceras ammonoid assemblage), the most frequent taxa are representatives of the family Tainoceratidae (Pleuronautilus, Metacoceras), followed by Grypoceratidae (Domatoceras), Koninckioceratidae (Endolobus) and Liroceratidae (Coelogasteroceras, Paranautilus).

A similar succession has also been recorded in other regions such as Transcaucasia (Shimansky, 1965; Gliwa et al., 2020). The changes in the composition are not caused by evo- 


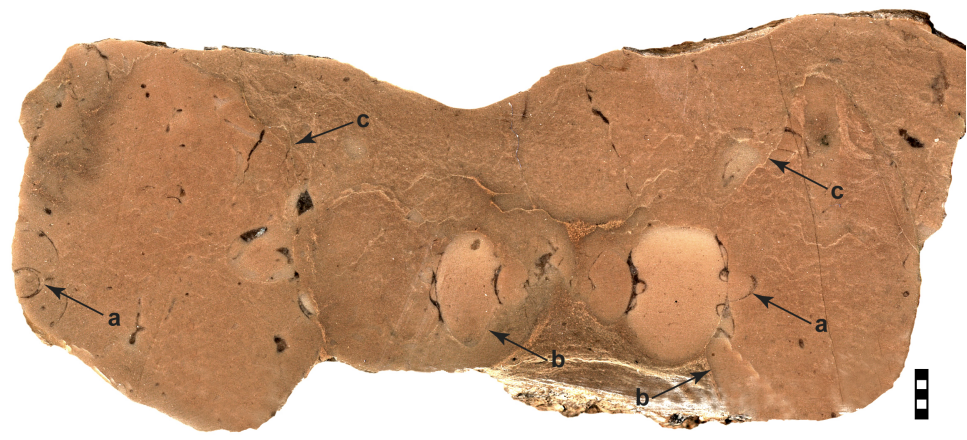

Figure 16. Example of ammonoid preservation in the upper Hambast Formation. Cross section of a specimen of Paratirolites sp. from Baghuk Mountain, MB.C.22215; note the different states of preservation of shell walls and septa: $a$ - recrystallized but rather well-preserved shell wall and septa preferably in the mid-dorsal portion of the ammonoid conch; $b$ - dissolved shell wall but sharp demarcation of the ammonoid's internal mould from the sediment at the lower side of the ammonoid conch; $c$ - dissolved shell wall and nearly continuous transition from the ammonoid's internal mould towards the sediment on the upper side of the ammonoid conch (from Leda et al., 2014). Scale bar units $=1 \mathrm{~mm}$.

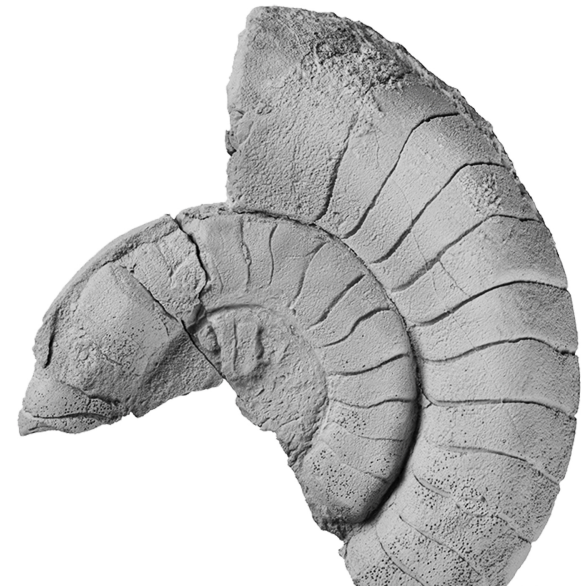

(a)

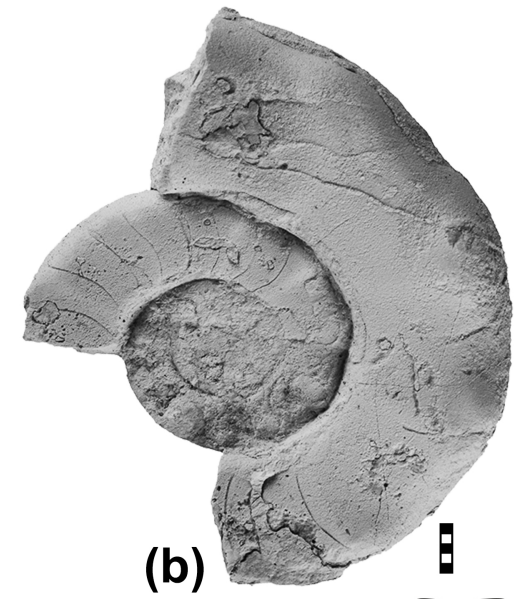

(b)
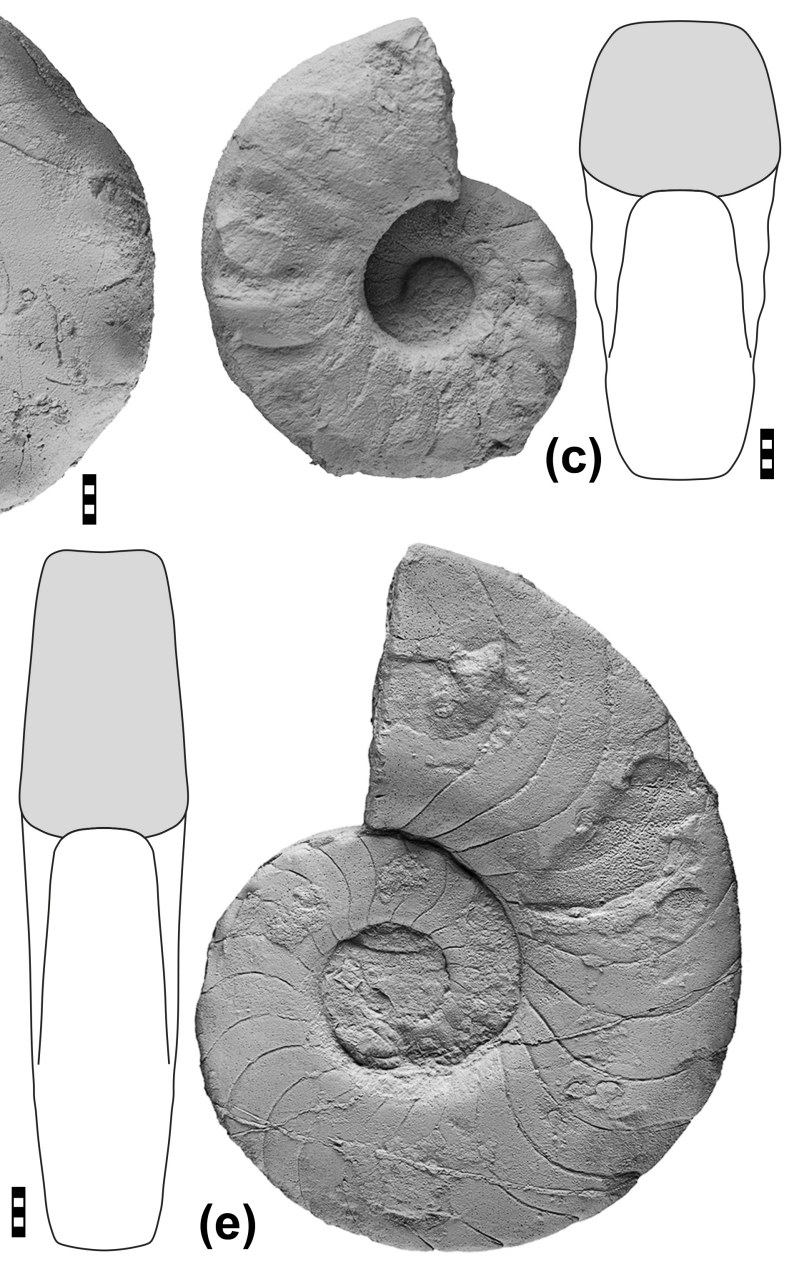

(e)

(d)

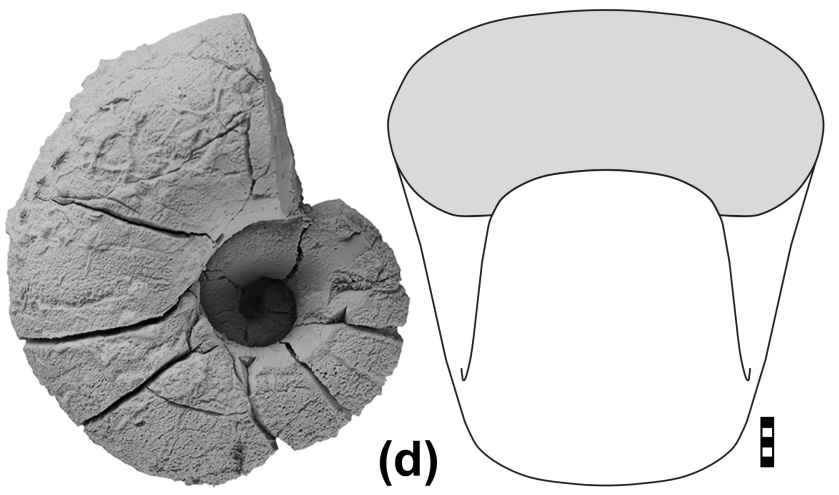

Figure 17. Selected nautiloid specimens indicative for the environmental change from the early (d, e) to the late Wuchiapingian (a-c); all specimens stored in the collection of the Museum für Naturkunde, Berlin. (a) Endolobus sp.; specimen MB.C.30223. (b) Metacoceras sp.; specimen MB.C.30224. (c) Pleuronautilus sp.; specimen MB.C.30225. (d) Permonautilus sp.; specimen MB.C.30226. (e) Domatoceras sp.; specimen MB.C.30227. Scale bar units $=1 \mathrm{~mm}$. 

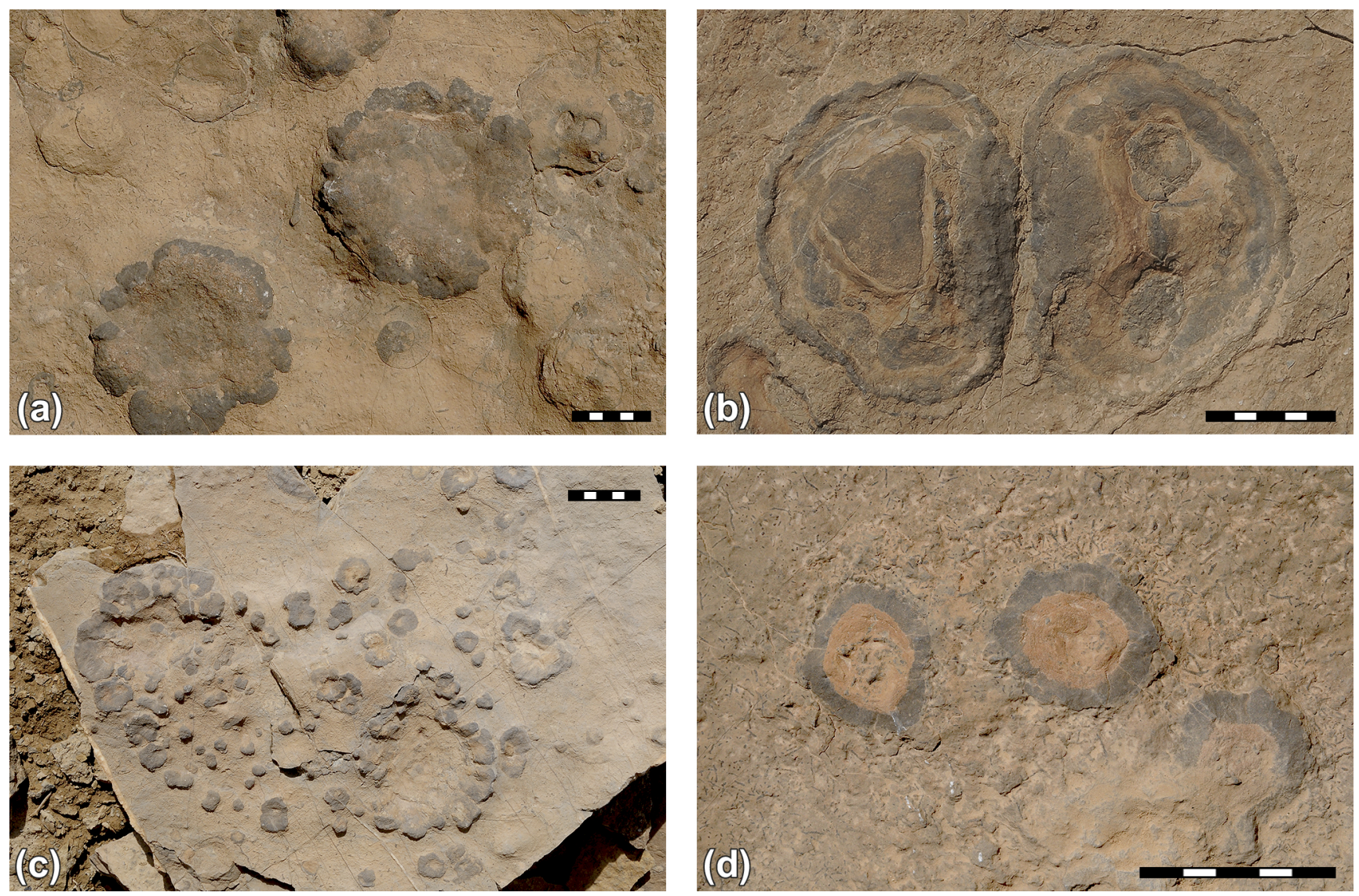

Figure 18. Field photographs of Early Triassic bedding surfaces with structures of possible microbial origin. (a) Flower-shaped structure in the pale-brown micritic matrix containing filaments, bivalve shell fragments, ammonoids and high-spired gastropods. (b) Kidney-shaped "twin" morphology characterized by an irregular, partly concentric structure, where micrite and sparite alternate. (c) Structures of different size, some of which grow on the margin of a previous generation. (d) Dark-grey, ovoidal, lenticular sparry calcite structure, filled by an argillaceous micrite, in pale-brown micritic matrix containing abundant filaments (probably sponge spicule remains).

lutionary changes but by facies changes (Korn et al., 2020); at Baghuk Mountain they parallel the deepening of the basin.

\section{Microbial buildups}

The occurrence of microbial structures in Early Triassic sedimentary rocks is a rather well-known phenomenon. Taraz et al. (1981) already described structures from the Kuh-e-Hambast sections, which they named "colonial limestones", and Heydari and Hassanzadeh (2003) and Heydari et al. (2008) described them as "Calcite Fans". Baud et al. $(2018,2021)$ discussed these structured in detail and identified them as digitate stromatolites.

At Baghuk Mountain, microbialitic structures occur at several places in the lowest $20 \mathrm{~m}$ of the Elikah Formation:

1. Baghuk Member. "Calcite Fans" (Fig. 11) occur in various frequency in the sections; while the westernmost section A has only one bed with "Calcite Fans", the northernmost section $\mathrm{K}$ has a series of successive lay- ers with "Calcite Fans" (Fig. 9). Descriptions and discussions were already provided by Leda et al. (2014), Heuer et al. (2017), Foster et al. (2020) and Leda (2020).

2. The interval between +7.00 and $+10.00 \mathrm{~m}$. Various beds in this interval show a variety of structures that may be of microbial origin. In morphology, they range from simply domed or club-shaped buildups with stromatolitic internal structure to rather complex, floweror mushroom-shaped geometry (Fig. 18). As an example of the most conspicuous of these microbial structures, we figure here a polished section (Fig. 19). It has a width of $70 \mathrm{~mm}$ and a height of about $65 \mathrm{~mm}$ and is composed of three parts: (a) a thick sparitic, partly laminated "holdfast", (b) an internal columnar structure that contains alternating layers of sparry calcite and mudto silt-sized material and (c) a "head" composed of a sparitic "brim" and sparitic "lid", the latter covering the entire structure. This "lid" is collapsed and cracked. It is striking that these individual structures closely resem- 


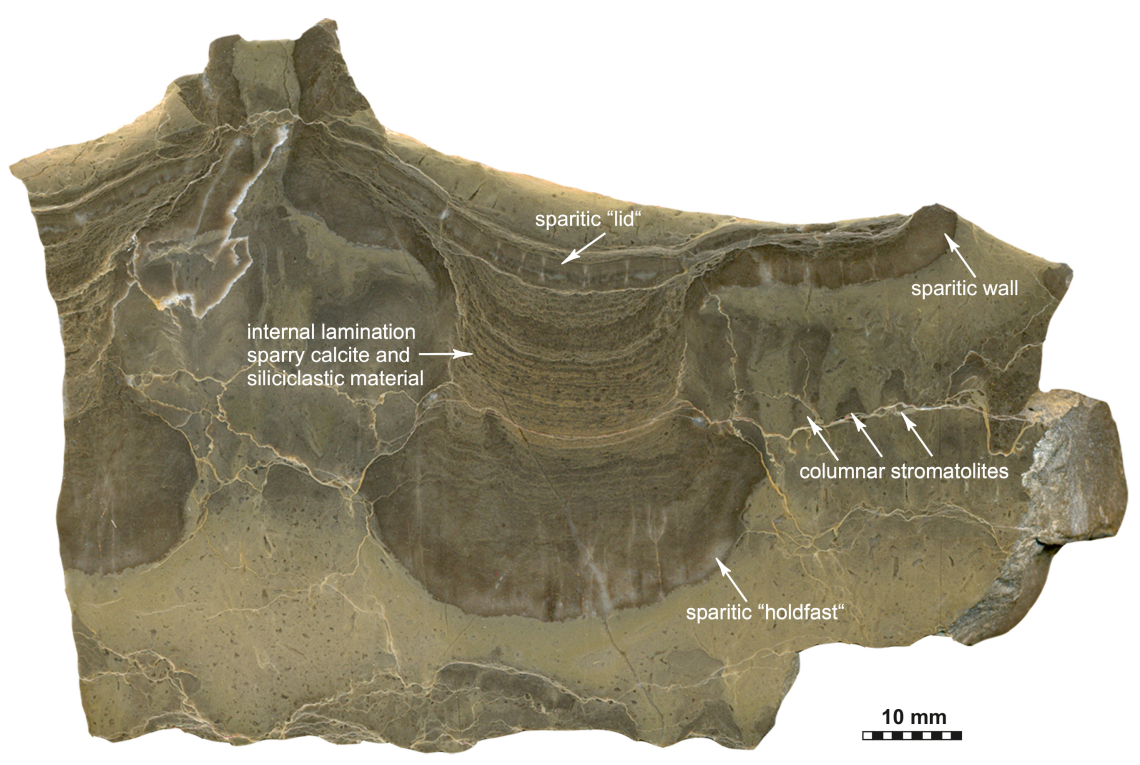

Figure 19. Polished slab of a mushroom-shaped structure of possible microbial origin, enclosed in a burrowed, partly recrystallized lime mudstone with remains of sponge spicules and small stromatolitic buildups. Scale bar units $=1 \mathrm{~mm}$.

ble each other and sometimes occur in groups of two or three in close neighbourhood but with clear separation.

3. Higher in the section, at $+19.70 \mathrm{~m}$ and higher, largerscaled dome-shaped morphologies with a branched internal structure occur occasionally.

A more detailed description of the microbialites will be provided in a separate study.

\section{Carbon isotopes}

We measured bulk-rock carbonate carbon isotopes from more than 90 samples spanning a rock interval from -10 to $+20 \mathrm{~m}$ with particular focus and dense sampling in the Permian-Triassic boundary interval between -2 and $+3 \mathrm{~m}$. Here, values are reported in the $\delta$-notation in per mille (\%o) relative to the Vienna Pee Dee Belemnite (VPDB), and with reproducibility of (ASK ULI), based on replicate analyses of an in-house standard (Solnhofen Limestone). For analytical details, see Gilg et al. (2003).

Carbon isotope chemostratigraphy has become a frequently applied tool for the construction of relative temporal frameworks of newly explored sites (Korte and Kozur, 2010; Schobben et al., 2019). The isotope curve (Fig. 20) generally resembles the curves from many other Permian-Triassic boundary sections in Iran (summarized by Schobben et al., 2017) such as Kuh-e-Hambast near Abadeh (Heydari et al., 2000; Korte et al., 2004b; Horacek et al., 2007; Korte et al., 2010; Richoz et al., 2010; Liu et al., 2013), Shahreza (Korte et al., 2004a; Heydari et al., 2008; Richoz et al., 2010) and NW Iran (Baud et al., 1989; Korte and Kozur, 2005; Kakuwa and Matsumoto, 2006; Richoz et al., 2010; Schobben et al., 2016; Gliwa et al., 2020), but it also shows some peculiarities:

1. The late Wuchiapingian and early Changhsingian values are around $+4 \%$, but already in the Clarkina changxingensis Zone, a weak negative trend can be recorded.

2. There is a continuous negative excursion across the late Changhsingian, which crosses the extinction horizon and extends throughout the "Boundary Clay" to values around $-1.5 \%$ at the first occurrence of Hindeodus parvus.

3. The total amplitude is $5.5 \%$ and thus higher than in many other Permian-Triassic boundary sections (Korte and Kozur, 2010; Schobben et al., 2017).

4. The Early Triassic shows an oscillating curve with values usually ranging between $-2 \%$ and $+1 \%$.

Amplitude differences in the first-order negative trend as recorded in bulk-rock carbonate $\delta^{13} \mathrm{C}$ from different $\mathrm{P}-\mathrm{Tr}$ sections globally, and sometimes also in close geographic proximity, are a frequently observed phenomenon (Meyer et al., 2010; Luo et al., 2014). A plethora of studies invoke a difference in the organic flux raining down on the seafloor related to primary productivity and export/burial efficiency (and possibly related to proximity to the position on the carbonate ramp) (Meyer et al., 2011; Luo et al., 2014). Nonetheless, such a mechanism would also require an earlydiagenetic process to imprint this signature of productivity (but not a complete reset of the original carbonate $\delta^{13} \mathrm{C}$ ) (Meyer et al., 2011; Luo et al., 2014), and therefore local 


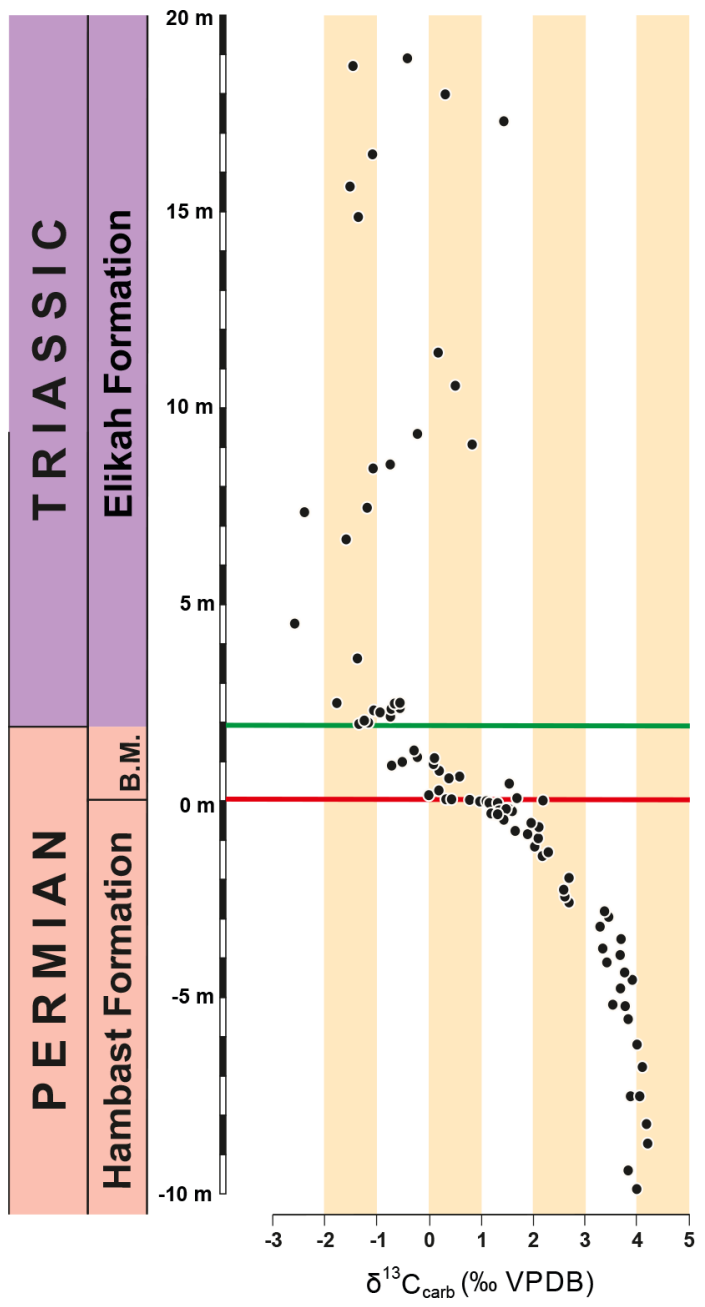

Figure 20. Succession of carbon isotopes $\left(\delta^{13} \mathrm{C}_{\mathrm{carb}}\right)$ in the Baghuk Mountain 1 and $\mathrm{C}$ sections (Hambast Formation and Elikah Formation, respectively).

sedimentary and redox conditions might also have played a prominent role in this geographically bound offset from the global $\delta^{13} \mathrm{C}$ curve (Schobben et al., 2017). Ignoring the offset in the amplitude, the first-order $\delta^{13} \mathrm{C}_{\text {carb }}$ trend over the studied interval is consistent with other P-Tr sections in Iran (Schobben et al., 2017), thereby further underpinning the stratigraphic completeness of the P-Tr transitional beds exposed at Baghuk Mountain.

\section{Conclusions}

Sections at Baghuk Mountain represent uninterrupted sedimentary successions across the P-Tr transition. Therefore, studies in this area are of great value in understanding the effects and possible causes of environmental changes in the transition from the Palaeozoic to the Mesozoic. These sections offer the opportunity to study the Wuchiapingian to Di- enerian sediment succession in terms of lithology, carbonate microfacies, fossil content (particularly ammonoids, bivalves, brachiopods, conodonts, ostracods and microbial deposits) and stable isotopes. In the following, we provide a first detailed description of various aspects of the PermianTriassic boundary layers at Baghuk Mountain.

The investigation of the lithology and fossil content of the little-explored Permian-Triassic boundary at Baghuk Mountain (Central Iran) led to the following results:

- Like the neighbouring sections near Shahreza and Abadeh, the sections at Baghuk Mountain consist of three lithostratigraphic units, in ascending order the Late Permian Hambast Formation, the youngest Permian Baghuk Member and the Early Triassic Claraia beds.

- The main Permian-Triassic extinction pulse has a position at the sharp lithological contact between the calcareous Hambast Formation and the Baghuk Member. The Late Permian carbonate factory deceased parallel to the main mass extinction pulse.

- In the post-extinction Elikah Formation, microbialites occur frequently with various, partly complex morphologies.

- The succession of conodont zones resembles those of the sections in NW Iran. However, there are two gaps in the record: one at the base of the Changhsingian and one in the latest Changhsingian. No conodonts were recorded between the Clarkina hauschkei Zone and the first entry of Hindeodus parvus.

- Three Wuchiapingian ammonoid assemblages are dominated by the genera Prototoceras, Pseudotoceras and Vedioceras, respectively. The Changhsingian part of the sections shows a dense succession of ammonoids with the most important genera Shevyrevites, Paratirolites, Alibashites, Abichites and Arasella. Arasella is the only genus that survived the main extinction pulse.

- While Griesbachian ammonoids are very rare, there is evidence for Dienerian ammonoids (genera Gyronites and Ussuridiscus) at a distance of $20 \mathrm{~m}$ above the extinction horizon.

- The Wuchiapingian part of the sections yielded two rather diverse nautiloid assemblages; the older of these is dominated by the families Liroceratidae and Grypoceratidae, while the younger is dominated by the Tainoceratidae as well as rarer Liroceratidae and Grypoceratidae.

- The carbon isotope curve $\left(\delta^{13} \mathrm{C}_{\text {carb }}\right)$ resembles the general Late Permian to Early Triassic data from other sections and regions. It differs from most of the others only in the apparently earlier start of the negative trend, 
which extends from the Clarkina changxingensis Zone throughout to the first occurrence of Hindeodus parvus.

- The carbonate deposition at Baghuk Mountain suggests a deep shelf environment, mostly below the storm wave base. Only during the Early Triassic, occasional shallowing led to chaotic deposition of bioclasts such as Claraia valves.

Data availability. Data $\left(\delta^{13} \mathrm{C}_{\mathrm{carb}}, \delta^{18} \mathrm{O}_{\mathrm{carb}}\right.$ values) related to this article are available in the Supplement.

Supplement. The supplement related to this article is available online at: https://doi.org/10.5194/fr-24-171-2021-supplement.

Author contributions. DK, LL, HMS, EF, AA, MS, AG, JG, DW and $\mathrm{VH}$ collected the investigated material in the field. US performed the lab analyses of stable isotopes. The various aspects were studied by DK, LL, HMS, AA, MS, AG, JG, VH and EF (lithological succession), MS and US (stable isotopes), EF and AG (conodonts) DK, DW and VH (ammonoids), DK (nautiloids), and LL, FH, HMS and VH (microbialites). All authors contributed to the concept of the study and writing of the manuscript.

Competing interests. The authors declare that they have no conflict of interest.

Disclaimer. Publisher's note: Copernicus Publications remains neutral with regard to jurisdictional claims in published maps and institutional affiliations.

Acknowledgements. We thank Markus Brinkmann (Berlin) for preparation and Jenny Huang (Berlin) for taking photographs of the cephalopod specimens. We also acknowledge the reviews of an earlier version by Eva Bischof (Bremen) and Aymon Baud (Lausanne).

Financial support. This research has been supported by the Deutsche Forschungsgemeinschaft (grant nos. Ko1829/12-1, Ko1829/15-1, Ko1829/18-1, and FOR 2332) and the Schweizerischer Nationalfonds zur Förderung der Wissenschaftlichen Forschung (grant no. P2ZHP3-168443).

The publication of this article was funded by the Open Access Fund of the Leibniz Association.

Review statement. This paper was edited by Christian Klug and reviewed by Aymon Baud and Eva Alexandra Bischof.

\section{References}

Alroy, J., Aberhan, M., Bottjer, D. J., Foote, M., Fürsich, F. T., Harries, P. J., Hendy, A. J. W., Holland, S. M., Ivany, L. C., Kiessling, W., Kosnik, M. A., Marshall, C. R., McGowan, A. J., Miller, A. I., Olszewski, T. D., Patzkowsky, M. E., Peters, S. E., Villier, L., Wagner, P. J., Bonuso, N., Borkow, P. S., Brenneis, B., Clapham, M. E., Fall, L. M., Ferguson, C. A., Hanson, V. L., Krug, A. Z., Layou, K. M., Leckey, E. H., Nürnberg, S., Powers, C. M., Sessa, J. A., Simpson, C., Tomasovych, A., and Visaggi, C. C.: Phanerozoic trends in the global diversity of marine invertebrates, Science, 321, 97-100, 2008.

Baghbani, D.: The Permian sequence in the Abadeh region, central Iran, Occasional Publication, Earth Sciences and Resources Institute, University of South Carolina, New Series B, 9, 7-22, 1993.

Bando, Y.: Upper Permian and Lower Triassic ammonoids from Abadeh, Central Iran, Memoirs of the Faculty of Education, Kagawa University, 23, 103-138, 1979.

Bando, Y.: Discovery of Lower Triassic ammonites in the Abadeh region of Central Iran, Geological Survey of Iran, Report, 49, 73-103, 1981

Barskov, I. S. and Koroleva, N. V.: Pervaya nakhodka verkhnepermskikh konodontov na territorii SSSR, Doklady Akademii Nauk SSSR, 194, 933-934, 1970.

Baud, A., Brönnimann, P., and Zaninetti, L.: Addendum, in: Etude lithologique et micropaléontologique de la formation d'Elika dans la coupe d'Aruh, edited by: Zaninetti, L., Brönnimann, P., Bozorgnia, F., and Huber, H., Alborz Central, Iran Septentrional, Archives des Sciences, Genève, 25, 244-248, 1972.

Baud, A., Cirilli, S., and Marcoux, J.: Biotic response to mass extinction: the lowermost Triassic microbialites, Facies, 36, 238242, 1997.

Baud, A., Magaritz, M., and Holser, W. T.: Permian-Triassic of the Tethys: Carbon isotope studies, Geol. Rundsch., 78, 649-677, 1989.

Baud, A., Richoz, S., Brandner, R., Krystyn, L., Heindel, K., Mohtat, T., and Mohtat-Aghai, P.: Sponge-microbial buildups: A new look at the enigmatic basal Triassic "Crystal Layers" of Central Iran, International Sedimentological Congress 2018, Québec City, 2018

Baud, A., Richoz, S., Brandner, R., Krystyn, L., Heindel, K., Mohtat, T., Mohtat-Aghai, P., and Horacek, M.: Sponge takeover from End-Permian mass extinction to early Induan time: Records in Central Iran microbial buildups, Front. Earth Sci., 8, 586210, https://doi.org/10.3389/feart.2021.586210, 2021.

Besse, J., Torcq, F., Gallet, Y., Ricou, L., Krystyn, L., and Saidi, A.: Late Permian to Late Triassic palaeomagnetic data from Iran: constraints on the migration of the Iranian block through the Tethyan Ocean and initial destruction of Pangaea, Geophys. J. Int.1, 135, 77-92, 1998.

Chen, J., Shen, S., Zhang, Y., Angiolini, L., Gorgij, M. N., Crippa, G., Wang, W., Zhang, H., Yuan, D., and Li, X.: Abrupt warming in the latest Permian detected using highresolution in situ oxygen isotopes of conodont apatite from Abadeh, central Iran, Palaeogeogr. Palaeocl., 560, 109973 , https://doi.org/10.1016/j.palaeo.2020.109973, 2020.

Dai, J. and Zhang, J.: Study on the Permian-Triassic biostratigraphy and event stratigraphy of northern Sichuan and southern Shaanxi, 
Ministry of Geology and Mineral Resources, Geological Memoirs, 2, 1-435, 1989.

Diener, C.: Triadische Cephalopodenfaunen der Ostsibirischen Küstenprovinz, Mémoires du Comité Géologique St. Pétersbourg, 14, 1-59, 1895.

Dudás, F. Ö., Yuan, D.-X., Shen, S.-Z., and Bowring, S. A.: A conodont-based revision of the ${ }^{87} \mathrm{Sr} /{ }^{86} \mathrm{Sr}$ seawater curve across the Permian-Triassic boundary, Palaeogeogr. Palaeocl., 470, 4053, 2017.

Erwin, D. H.: The great Paleozoic crisis: life and death in the Permian, Columbia University Press, New York, 327 pp., 1993.

Erwin, D. H.: The Permo-Triassic extinction, Nature, 367, 231-236, 1994.

Erwin, D. H., Bowring, S. A., and Jin, Y.: End-Permian mass extinctions: a review, Special Papers-Geological Society of America, 356, 363-384, 2002.

Farshid, E., Hamdi, B., Hairapetian, V., and Aghanabati, S. A.: Conodont biostratigraphy of the Permian-Triassic boundary in the Baghuk mountain section Northwest of Abadeh, Scientific Quarterly Journal, Geosciences, 25, 285-294, 2016.

Foster, W. J., Heindel, K., Richoz, S., Gliwa, J., Lehrmann, D. J., Baud, A., Kolar-Jurkovšek, T., Aljinović, D., Jurkovšek, B., Korn, D., Martindale, R. C., and Peckmann, J.: Suppressed competitive exclusion enabled the proliferation of Permian/Triassic boundary microbialites, The Depositional Record, 6, 62-74, 2020.

Friesenbichler, E., Richoz, S., Baud, A., Krystyn, L., Sahakyan, L., Vardanyan, S., Peckmann, J., Reitner, J., and Heindel, K.: Sponge-microbial buildups from the lowermost Triassic Chanakhchi section in southern Armenia: Microfacies and stable carbon isotopes, Palaeogeogr. Palaeocl., 490, 653-672, 2018.

Gallet, Y., Krystyn, L., Besse, J., Saidi, A., and Ricou, L. E.: New constraints on the Upper Permian and Lower Triassic geomagnetic polarity timescale from the Abadeh section (central Iran), J. Geophys. Res.-Sol. Ea., 105, 2805-2815, 2000.

Ghaderi, A.: Stratigraphy and paleoecology of the Upper Permian to Permian - Triassic boundary in the northwest of Iran based on biostratigraphic data of conodonts and brachiopods, Ferdowsi University of Mashhad, Mashhad, 488 pp., 2014.

Ghaderi, A., Leda, L., Schobben, M., Korn, D., and Ashouri, A. R.: High-resolution stratigraphy of the Changhsingian (Late Permian) successions of NW Iran and the Transcaucasus based on lithological features, conodonts and ammonoids, Foss. Rec., 17, 41-57, https://doi.org/10.5194/fr-17-41-2014, 2014.

Ghaedi, M., Mousavi, N., and Yazdi, M.: Scrutiny and biozonation of Permian - Triassic boundary in Benarizeh area, north of Abadeh, Second conference of the Iranian Paleontological Association, 2009

Ghorbani, M.: The economic geology of Iran: mineral deposits and natural resources, Springer Science \& Business Media, Dordrecht, 569 pp., 2013.

Gilg, H. A., Struck, U., Vennemann, T., and Boni, M.: Phosphoric acid fractionation factors for smithsonite and cerussite between 25 and $72^{\circ} \mathrm{C}$, Geochim. Cosmochim. Ac., 67, 4049-4055, 2003.

Gliwa, J., Ghaderi, A., Leda, L., Schobben, M., Tomás, S., Foster, W. J., Forel, M.-B., Ghanizadeh Tabrizi, N., Grasby, S. E., Struck, U., Ashouri, A. R., and Korn, D.: Aras Valley (northwest Iran): high-resolution stratigraphy of a continuous central
Tethyan Permian-Triassic boundary section, Foss. Rec., 23, 3369, 2020.

Hampe, O., Hairapetian, V., Dorka, M., Witzmann, F., Akbari, A. M., and Korn, D.: A first late Permian fish fauna from Baghuk Mountain (Neo-Tethyan shelf, central Iran), Bull. Geosci., 88, 1-20, 2013.

Hassanzadeh, J. and Wernicke, B. P.: The Neotethyan SanandajSirjan zone of Iran as an archetype for passive margin-arc transitions, Tectonics, 35, 586-621, 2016.

Henderson, C. M., Shilong, M., Shen, S., and Wardlaw, B. R.: Resolution of the reported Upper Permian conodont occurrences from northwestern Iran, Permophiles, 51, 2-9, 2008.

Heuer, F., Leda, L., Korn, D., Hairapetian, V., and Moradi Salimi, H.: Early Triassic microbialites at Baghuk Mountain (Central Iran), Goldschmidt Conference, Paris 2017, 2017.

Heuer, F., Leda, L., Moradi Salimi, H., Gliwa, J., Hairapetian, V., and Korn, D.: The Permian-Triassic boundary section at Baghuk Mountain, Central Iran: carbonate microfacies and depositional environment, Palaeobio. Palaeoenv., submitted, 2021.

Heydari, E. and Hassanzadeh, J.: Deev Jahi model of the PermianTriassic boundary mass extinction: a case for gas hydrates as the main cause of biological crisis on Earth, Sediment. Geol., 163, 147-163, 2003.

Heydari, E., Hassandzadeh, J., and Wade, W.: Geochemistry of central Tethyan upper Permian and lower Triassic strata, Abadeh region, Iran, Sediment. Geol., 137, 85-99, 2000.

Heydari, E., Wade, W. J., and Hassanzadeh, J.: Diagenetic origin of carbon and oxygen isotope compositions of Permian-Triassic boundary strata, Sediment. Geol., 143, 191-197, 2001.

Heydari, E., Hassanzadeh, J., Wade, W., and Ghazi, A.: PermianTriassic boundary interval in the Abadeh section of Iran with implications for mass extinction: Part 1 - Sedimentology, Palaeogeogr. Palaeocl., 193, 405-423, 2003.

Heydari, E., Arzani, N., and Hassanzadeh, J.: Mantle plume: the invisible serial killer - application to the Permian-Triassic boundary mass extinction, Palaeogeogr. Palaeocl., 264, 147-162, 2008.

Heydari, E., Arzani, N., Safaei, M., and Hassanzadeh, J.: Ocean's response to a changing climate: Clues from variations in carbonate mineralogy across the Permian-Triassic boundary of the Shareza Section, Iran, Glob. Planet. Change, 105, 79-90, 2013.

Horacek, M., Richoz, S., Brandner, R., Krystyn, L., and Spötl, C.: Evidence for recurrent changes in Lower Triassic oceanic circulation of the Tethys: the $\delta^{3} \mathrm{C}$ record from marine sections in Iran, Palaeogeogr. Palaeocl., 252, 355-369, 2007.

Horacek, M., Krystyn, L., and Baud, A.: Comment to Chen et al., 2020: "Abrupt warming in the latest Permian detected using high-resolution in situ oxygen isotopes of conodont apatite from Abadeh, central Iran”, Importance of correct stratigraphic correlation, reporting of existing data and their scientific interpretation, Permophiles, 70, 33-36, 2021.

Huckriede, R.: Die Conodonten der mediterranen Trias und ihr stratigraphischer Wert, Paläontol. Z., 32, 141-175, 1958.

Jin, Y., Wang, Y., Wang, W., Shang, Q., Cao, C., and Erwin, D.: Pattern of marine mass extinction near the Permian-Triassic boundary in South China, Science, 289, 432-436, 2000.

Kakuwa, Y. and Matsumoto, R.: Cerium negative anomaly just before the Permian and Triassic boundary event - the upward expansion of anoxia in the water column, Palaeogeogr. Palaeocl., 229, 335-344, 2006. 
Kiessling, W., Schobben, M., Ghaderi, A., Hairapetian, V., Leda, L., and Korn, D.: Pre-mass extinction decline of latest Permian ammonoids, Geology, 46, 283-286, 2018.

Korn, D. and Ghaderi, A.: The Late Permian araxoceratid ammonoids: a case of repetitive temporal and spatial unfolding of homoplastic conch characters, Neues Jahrb. Geol. P.-A., 292, 339-350, 2019.

Korn, D., Ghaderi, A., Leda, L., Schobben, M., and Ashouri, A. R.: The ammonoids from the Late Permian Paratirolites Limestone of Julfa (East Azerbaijan, Iran), J. Syst. Palaeontol., 14, 841-890, 2016.

Korn, D., Ghaderi, A., and Ghanizadeh Tabrizi, N.: Early Changhsingian (Late Permian) ammonoids from NW Iran, Neues Jahrb. Geol. P.-A., 293, 37-56, 2019.

Korn, D., Ghaderi, A., Ghanizadeh Tabrizi, N., and Gliwa, J.: The morphospace of Late Permian coiled nautiloids, Lethaia, 53, 154-165, 2020.

Korn, D., Hairapetian, V., Ghaderi, A., Leda, L., Schobben, M., and Akbari, A.: The Changhsingian (Late Permian) ammonoids from Baghuk Mountain (Central Iran), Eur. J. Taxon., submitted, 2021.

Korte, C. and Kozur, H. W.: Carbon isotope stratigraphy across the Permian/Triassic boundary at Jolfa (NW-Iran), Peitlerkofel (Sass de Pütia, Sass de Putia), Pufels (Bula, Bulla), Tesero (all three Southern Alps, Italy) and Gerennavár (Bükk Mts., Hungary), J. Alp. Geol., 47, 119-135, 2005.

Korte, C. and Kozur, H. W.: Carbon-isotope stratigraphy across the Permian-Triassic boundary: a review, J. Asian Earth Sci., 39, 215-235, 2010.

Korte, C., Kozur, H. W., and Mohtat-Aghai, P.: Dzhulfian to lowerest Triassic delta $\delta^{13} \mathrm{C}$ record at the Permian/Triassic boundary section at Shahreza, Central Iran, Hallesches Jahrbuch für Geowissenschaften, Reihe B, Beiheft, 18, 73-78, 2004 a.

Korte, C., Kozur, H. W., Joachimski, M. M., Strauss, H., Veizer, J., and Schwark, L.: Carbon, sulfur, oxygen and strontium isotope records, organic geochemistry and biostratigraphy across the Permian/Triassic boundary in Abadeh, Iran, Int. J. Earth Sci., 93, 565-581, 2004b.

Korte, C., Pande, P., Kalia, P., Kozur, H. W., Joachimski, M. M., and Oberhänsli, H.: Massive volcanism at the Permian-Triassic boundary and its impact on the isotopic composition of the ocean and atmosphere, J. Asian Earth Sci., 37, 293-311, 2010.

Kozur, H. and Pjatakova, M.: Die Conodontenart Anchignathodus parvus n. sp., eine wichtige Leitform der basalen Trias, Koninklijke Nederlandse Akademic van Wetenschappen, Proc. Ser. B, 79, 123-128, 1976.

Kozur, H. W.: Pelagic uppermost Permian and the Permian-Triassic boundary conodonts of Iran: Part I: taxonomy, Hallesches Jahrbuch für Geowissenschaften, Reihe B, Beiheft, 18, 39-68, 2004.

Kozur, H. W.: Pelagic uppermost Permian and the Permian-Triassic boundary conodonts of Iran, Part II: Investigated sections and evaluation of the conodont faunas, Hallesches Jahrbuch für Geowissenschaften, Reihe B, Beiheft, 19, 49-86, 2005.

Kozur, H. W.: Biostratigraphy and event stratigraphy in Iran around the Permian-Triassic Boundary (PTB): implications for the causes of the PTB biotic crisis, Glob. Planet. Change, 55, 155176, 2007.
Leda, L.: The Permian-Triassic boundary in the NW-Iranian Transcaucasus and in Central Iran, Humboldt-Universität zu Berlin, 222 pp., https://doi.org/10.18452/21106, 2020.

Leda, L., Korn, D., Ghaderi, A., Hairapetian, V., Struck, U., and Reimold, W. U.: Lithostratigraphy and carbonate microfacies across the Permian-Triassic boundary near Julfa (NW Iran) and in the Baghuk Mountains (Central Iran), Facies, 60, 295-325, 2014.

Liu, X., Wang, W., Shen, S., Gorgij, M. N., Ye, F., Zhang, Y., Furuyama, S., Kano, A., and Chen, X.: Late Guadalupian to Lopingian (Permian) carbon and strontium isotopic chemostratigraphy in the Abadeh section, central Iran, Gondwana Res., 24, 222 232, 2013.

Luo, G., Algeo, T. J., Huang, J., Zhou, W., Wang, Y., Yang, H., Richoz, S., and Xie, S.: Vertical $\delta^{13}$ Corg gradients record changes in planktonic microbial community composition during the endPermian mass extinction, Palaeogeogr. Palaeocl., 396, 119-131, 2014.

Mei, S., Zhang, K., and Wardlaw, B. R.: A refined succession of Changhsingian and Griesbachian neogondolellid conodonts from the Meishan section, candidate of the global stratotype section and point of the Permian-Triassic boundary, Palaeogeogr. Palaeocl., 143, 213-226, 1998.

Meyer, K., Yu, M., Jost, A., Kelley, B., and Payne, J.: $\delta^{13} \mathrm{C}$ evidence that high primary productivity delayed recovery from endPermian mass extinction, Earth Planet. Sc. Lett., 302, 378-384, 2011.

Muttoni, G., Gaetani, M., Kent, D. V., Sciunnach, D., Angiolini, L., Berra, F., Garzanti, E., Mattei, M., and Zanchi, A.: Opening of the Neo-Tethys Ocean and the Pangea B to Pangea A transformation during the Permian, GeoArabia, 14, 17-48, 2009.

Nabavi, M. H.: An introduction to the geology of Iran, Geological Survey of Iran, Tehran, 109 pp., 1976.

Partoazar, H.: Permian-Triassic boundary conodonts from JolfaAbadeh Belt along Northwest and Central Iran, Permophiles, 41, 34-40, 2002.

Richoz, S., Krystyn, L., Baud, A., Brandner, R., Horacek, M., and Mohtat-Aghai, P.: Permian-Triassic boundary interval in the Middle East (Iran and N. Oman): Progressive environmental change from detailed carbonate carbon isotope marine curve and sedimentary evolution, J. Asian Earth Sci., 39, 236-253, 2010.

Ruban, D. A., Al-Husseini, M. I., and Iwasaki, Y.: Review of Middle east Paleozoic plate tectonics, GeoArabia, 12, 35-56, 2007.

Ruzhencev, V. E.: Klassifikatsia nadsemeystva Otocerataceae, Paleontologicheskiy Zhurnal, 1959, 56-67, 1959.

Ruzhencev, V. E.: Klassifikatsia semeystve Araxoceratidae., Paleontologicheskiy Zhurnal, 1962, 88-103, 1962.

Ruzhencev, V. E.: Novye dannye o semeystve Araxoceratidae., Paleontologicheskiy Zhurnal, 1963, 56-64, 1963.

Ruzhencev, V. E.: Izmenenie organicheskovo mira na rubezhe Paleozoya i Mezozoyia, in: Razvitie i smena morskikh organizmov na Rubezhe Paleozoia i Mezozoia, edited by: Ruzhencev, V. E. and Sarycheva, T. G., Trudy Paleontologicheskogo Instituta Akademiya Nauk SSSR, 108, 117-134, 1965.

Ruzhencev, V. E. and Shevyrev, A. A.: Ammonoidei, in: Razvitie i smena morskikh organizmov na Rubezhe Paleozoya i Mezozoya, edited by: Ruzhencev, V. E. and Sarytcheva, T. G., Trudy Paleontologicheskogo Instituta Akademiya Nauk SSSR, 108, 47-57, 1965 . 
Sahakyan, L., Baud, A., Grigoryan, A., Friesenbichler, E., and Richoz, S. (Eds.): The Permian-Triassic transition in Southern Armenia, 5th IGCP 630 International conference and field workshop, 8-14 10, 2017, National Academy of Sciences of the Armenia Republic, Institute of Geological Sciences, Yerevan, Field Guide-Book 1-53, 2017.

Schobben, M., Ullmann, C. V., Leda, L., Korn, D., Struck, U., Reimold, W. U., Ghaderi, A., Algeo, T. J., and Korte, C.: Discerning primary versus diagenetic signals in carbonate carbon and oxygen isotope records: An example from the Permian-Triassic boundary of Iran, Chem. Geol., 422, 94-107, 2016.

Schobben, M., van de Velde, S., Gliwa, J., Leda, L., Korn, D., Struck, U., Ullmann, C. V., Hairapetian, V., Ghaderi, A., Korte, C., Newton, R. J., Poulton, S. W., and Wignall, P. B.: Latest Permian carbonate carbon isotope variability traces heterogeneous organic carbon accumulation and authigenic carbonate formation, Clim. Past, 13, 1635-1659, https://doi.org/10.5194/cp-131635-2017, 2017.

Schobben, M., Van De Schootbrugge, B., and Wignall, P. B.: Interpreting the carbon isotope record of mass extinctions, Elements: An International Magazine of Mineralogy, Geochem. Petrol., 15, 331-337, 2019.

Şengör, A. C.: Mid-Mesozoic closure of Permo-Triassic Tethys and its implications, Nature, 279, 590-593, 1979.

Shen, S. and Mei, S.: Lopingian (Late Permian) high-resolution conodont biostratigraphy in Iran with comparison to South China zonation, Geol. J., 45, 135-161, 2010.

Shevyrev, A. A.: Nadortyad Ammonoidea, in: Rasvitie i smena morskikh organizmov na rubezhe Paleozoya i Mezozoya, edited by: Ruzhencev, V. E. and Sarytcheva, T. G., Trudy Paleontologicheskogo Instituta Akademiya Nauk SSSR, 108, 166-182, 1965.

Shevyrev, A. A.: Triasovye ammonoidei Yuga SSSR, Trudy Paleontologicheskogo Instituta Akademiya Nauk SSSR, 119, 1-272, 1968.

Shimansky, V. N.: Podotryad Nautiloidea, in: Razvitie i smena morskikh organizmov na Rubezhe Paleozoya i Mezozoya, edited by: Ruzhencev, V. E. and Sarytcheva, T. G., Trudy Paleontologicheskogo Instituta Akademiya Nauk SSSR, 108, 157-165, 1965.

Song, H., Wignall, P. B., Tong, J., and Yin, H.: Two pulses of extinction during the Permian-Triassic crisis, Nat. Geosci., 6, 52-56, 2013.

Stampfli, G., Zaninetti, L., Brönimann, P., Jenny-Deshusses, C., and Stampfli-Vuille, B.: Trias de l'Elburz oriental, Iran. Stratigraphie, sédimentologie, micropaléontologie, Rivista Italiana di Paleontologia, 82, 467-500, 1976.

Stampfli, G. M. and Borel, G.: A plate tectonic model for the Paleozoic and Mesozoic constrained by dynamic plate boundaries and restored synthetic oceanic isochrons, Earth Planet. Sc. Lett., 196, 17-33, 2002.
Stampfli, G. M. and Borel, G. D.: The TRANSMED transects in space and time: constraints on the paleotectonic evolution of the Mediterranean domain, in: The TRANSMED Atlas, The Mediterranean region from crust to mantle, Springer, 53-80, 2004.

Stöcklin, J.: Structural history and tectonics of Iran: a review, AAPG Bulletin, 52, 1229-1258, 1968.

Taraz, H.: Permo-Triassic section in central Iran, AAPG Bull., 53, 688-693, 1969.

Taraz, H.: Uppermost Permian and Permo-Triassic transition beds in central Iran, AAPG Bull., 55, 1280-1294, 1971.

Taraz, H.: Correlation of uppermost Permian in Iran, central Asia, and south China, AAPG Bull., 57, 1117-1133, 1973.

Taraz, H.: Geology of the Surmaq Deh Bid Area, Abadeh Region, Central Iran, Geological Survey of Iran, Reports, 37, 1-148, 1974.

Taraz, H., Golshani, F., Nakazawa, K., Sgimuzu, D., Bando, Y., Ishi, K., Murata, M., Okimura, Y., Sakagami, S., Nakamura, K., and Tokuoka, T.: The Permian and the Lower Triassic systems in Abadeh region, central Iran, Memoirs of the Faculty of Science, Kyoto University, Ser. Geol. Mineral., 47, 61-133, 1981.

Teichert, C., Kummel, B., and Sweet, W. C.: Permian-Triassic strata, Kuh-e-Ali Bashi, Northwestern Iran., Bulletin of the $\mathrm{Mu}-$ seum of Comparative Zoology, Harvard University, 145, 359472, 1973.

Torsvik, T. H. and Cocks, L. R. M.: Earth geography from 400 to 250 Ma: a palaeomagnetic, faunal and facies review, J. Geol. Soc., 161, 555-572, 2004.

von Krafft, A. and Diener, C.: Lower Triassic cephalopoda from Spiti, Malla Johar, and Byans, Palaeontologia Indica, 6, 1-186, 1909.

Wang, C. and Wang, Z.: Permian conodont biostratigraphy of China, Geol. Soc. Am. Spec. Papers, 187, 227-236, 1981.

Yazdi, M. and Shirani, M.: First research on marine and nonmarine sedimentary sequences and micropaleontologic significance across Permian/Triassic boundary in Iran (Isfahan and Abadeh), J. China Univ. Geosci., 13, 172-176, 2002.

Yin, H., Zhang, K., Tong, J., Yang, Z., and Wu, S.: The global stratotype section and point (GSSP) of the Permian-Triassic boundary, Episodes, 24, 102-114, 2001.

Zakharov, Y. D.: The Permo-Triassic boundary in the southern and eastern USSR and its intercontinental correlation, in: Stratigraphy, classification and relations with the western Tethys, World and Regional Geology 2, edited by: Sweet, W. C., Zunyi, Y., Dickins, J. M., and Hongfu, Y., Cambridge University Press, Cambridge, 46-55, 1992.

Zakharov, Y. D., Abnavi, N. M., Yazdi, M., and Ghaedi, M.: New species of Dzhulfian (Late Permian) ammonoids from the Hambast Formation of Central Iran, Paleontol. J., 44, 614-621, 2010. 